\title{
Genetic Mapping and Characterization of Lethal Necrotic Mutants in Rice (Oryza sativa L.)
}

\author{
Rumanzi Saidi Mbaraka, Yoshiyuki Yamagata, Atsushi Yoshimura, Hideshi Yasui* \\ Plant Breeding Laboratory, Faculty of Agriculture, Kyushu University, Fukuoka, Japan \\ Email: ^hyasui@agr.kyushu-u.ac.jp
}

How to cite this paper: Mbaraka, R.S., Yamagata, Y., Yoshimura, A. and Yasui, $\mathrm{H}$. (2017) Genetic Mapping and Characterization of Lethal Necrotic Mutants in Rice (Oryza sativa L.). American Journal of Plant Sciences, 8, 3350-3376.

https://doi.org/10.4236/ajps.2017.813226

Received: November 7, 2017

Accepted: December 15, 2017

Published: December 18, 2017

Copyright $\odot 2017$ by authors and Scientific Research Publishing Inc. This work is licensed under the Creative Commons Attribution International License (CC BY 4.0).

http://creativecommons.org/licenses/by/4.0/

\begin{abstract}
The spread of tissue necrosis leads to plant death. We isolated 18 lethal necrotic mutants induced in rice (Oryza sativa L.) by gamma-irradiation. The necrotic lethality among the 18 mutants was controlled by single recessive genes designated necrotic lethalityl (nec1) to necl 8 . These mutants display pale-green leaves from the third-leaf stage and leaf-tip necrosis, which spreads to the whole plant, killing it. Genetic mapping and histochemical analysis of the lethal necrotic mutants were conducted. At least four independent loci on chromosomes 2 and 4 controlled necrotic lethality. Therefore, the genetic causes of lethal necrosis vary among mutant stocks. Histochemical analysis at 12 days after sowing showed that $\mathrm{H}_{2} \mathrm{O}_{2}$ accumulated in the necrotic parts of leaves, and that cell death occurred throughout the leaf. Mutants for early necrotic lethality ( $<24$ days to lethality) were characterized by the rapid spread of $\mathrm{H}_{2} \mathrm{O}_{2}$ accumulation throughout the third leaf. Mutants for late necrotic lethality ( $>35$ days to lethality) were characterized by the incomplete spread of $\mathrm{H}_{2} \mathrm{O}_{2}$ accumulation within the third leaf.
\end{abstract}

\section{Keywords}

Rice, Mutant, Necrotic Lethality, Linkage Mapping, Reactive Oxygen Species

\section{Introduction}

Necrosis of plant tissues usually shows as brown or black discoloration. Stresses such as fungal infections can cause necrosis in any tissues [1]. Necrosis is common in relation to nutrient supply; for example, deficiencies in potassium can cause severe necrotic lesions in leaves [2] [3] [4] [5] [6]. In addition, hybrid necrosis, caused by deleterious epistatic interactions, results from spontaneous activation of plant defenses associated with leaf necrosis [7] [8] [9]. Necrotic lesion formation has been reported in several mutants. The maize lethal leaf spot 1 
(IIs1) shows enhanced resistance to fungal infections due to necrotic lesion formation [10]. The Arabidopsis botrytis-susceptible 1 (bos1) mutant develops necrosis to resist infection by Dickeya dadantii [11]. Several lesion mimic mutants (LMMs) of rice show broad-spectrum resistance to blast and bacterial blight [12]. Excessive phosphate accumulates in the shoots of the phosphate-accumulator 2 (pho2) mutant of Arabidopsis, which develops necrotic symptoms [13] [14]. The rice leaf tip necrosis 1 (Itn1) mutant lacks a protein containing a ubiquitin-conjugating domain, which regulates phosphate accumulation, and develops leaf tip necrosis [15]. The phenotypes in most lesion mimic and necrotic mutants are often influenced by environmental factors [16]. Light and temperature affect the severity of mutant phenotypes in rice zebra necrosis [17] and faded green leaf [18] mutants and maize lls1 mutants [10] [19]. Under short-day conditions, a barley lesion-mimic mutant, "1661", fails to reach maturity and does not produce seeds [20]. These mutants can survive to maturity. In addition, mutants in which necrosis spreads to the whole plant have been reported in maize: at least eight recessive mutants (nec1 - nec7, nec- $t$, [21] [22] showed leaf discoloration, necrotic leaf tips, spots, or transverse bands before death. However, rice mutants showing necrotic lethality have not yet been isolated. In plants, reactive oxygen species (ROS) such as hydrogen peroxide $\left(\mathrm{H}_{2} \mathrm{O}_{2}\right)$, superoxide and hydroxyl radicals are constantly produced as metabolic byproducts in chloroplasts, mitochondria, and peroxisomes [23] [24]. Under stress, ROS production exceeds the cells' scavenging capacity, and the ROS radicals induce necrotic lesions and alter the expression of certain genes in many signaling pathways, eventually leading to accelerated cell death [23] [24]. In maize, Arabidopsis, and rice [25] [26] [27] [28], the accumulation of ROS in particular, $\mathrm{H}_{2} \mathrm{O}_{2}$ and the presence of dead cells are studied as biochemical markers constitutively expressed in LMMs [29]. They are commonly monitored by staining using histochemical dyes: 3',3'-diaminobenzidine (DAB) and trypan blue, respectively [29] [30]. Although $\mathrm{H}_{2} \mathrm{O}_{2}$ is known to cause cell death leading to necrotic lesions in many plants [31], little is known about ROS-induced necrotic lethality. In this study, we isolated 18 gamma-irradiated rice mutants with necrotic lethality at the seedling stage. We analyzed them to map the genes responsible for their necrotic lethality and histochemically characterized them for $\mathrm{H}_{2} \mathrm{O}_{2}$ accumulation and cell death.

\section{Materials and Methods}

\subsection{Plant Materials}

Two rice cultivars; a japonica cultivar, "Taichung 65" (T65) and indica cultivar "IR24" were gamma irradiated as described by Yamagata et al. [32]. The spikelets of these cultivars were exposed to 100 - 150 Gy dosage just before anthesis using the $\mathrm{Co}^{60} \gamma$-ray irradiation facility of Institute for Irradiation and Analysis of Quantum Radiation, Kyushu University. Self-pollinated $M_{1}$ plants were grown and $M_{2}$ seeds were harvested and used to generate $M_{3}$ plants. Self-pollination and screening of these mutant stocks were conducted and the resulting mutant 
stocks were maintained in the Plant Breeding Laboratory, Kyushu University. These mutants were designed as LEM (lethal mutants) (Table 1). Seeds of the mutant lines were sown on 25 May 2016 on sieved soil containing $2.63 \mathrm{~g} \cdot \mathrm{m}^{-2}$ of NPK, and the seedlings were grown in a greenhouse under natural conditions at Kyushu University Farm, Fukuoka, Japan $\left(33^{\circ} 36^{\prime} 55^{\prime \prime N}\right)$. For phenotypic characterization, ten plants were observed per mutant line. Surviving nec1 8 mutant seedlings were transplanted into the paddy field and observed until 15 August 2016. For histochemical analysis, plants were grown in a phytotron maintained at $25^{\circ} \mathrm{C}$ under natural sunlight in 2016 and 2017 at Kyushu University. For genetic mapping of the mutants, we crossed the wild-type segregants of twelve T65-derived mutant lines, LEM1 (nec1), LEM2 (nec18), LEM9 (nec4), LEM11 (nec16), LEM16 (nec5), LEM17 (nec6), LEM18 (nec8), LEM20 (nec14), LEM25 (nec15), LEM29 (nec9), LEM36 (nec10), and LEM37 (nec11) with japonica cultivar "Hinohikari", and crossed normal segregants of two IR24_derived mutant lines, LEM41 (nec17) and LEM43 (nec13) with T65. The resulting $\mathrm{F}_{2}$ populations in which necrotic lethality segregated were used to map necrosis genes.

Table 1. Identification of genes responsible for necrotic lethality in the 18 mutant lines.

\begin{tabular}{|c|c|c|c|c|c|c|c|c|c|}
\hline \multirow{2}{*}{ Gene } & \multirow{2}{*}{$\begin{array}{c}\text { Mutant } \\
\text { line }\end{array}$} & \multirow{2}{*}{ Background } & \multirow{2}{*}{ DTL } & \multicolumn{3}{|c|}{$\begin{array}{l}\text { Segregation for } \\
\text { necrotic lethality }\end{array}$} & \multirow{2}{*}{$P^{a}$} & \multirow{2}{*}{ BSA } & \multirow{2}{*}{$\begin{array}{c}\mathrm{H}_{2} \mathrm{O}_{2} \\
\text { accumulation }^{\mathrm{b}}\end{array}$} \\
\hline & & & & $\begin{array}{l}\text { Wild } \\
\text { type }\end{array}$ & $\begin{array}{l}\text { Necrotic } \\
\text { lethality }\end{array}$ & Total & & & \\
\hline necl & LEM1 & T65 & 16 & 68 & 21 & 89 & 0.76 & $2 \mathrm{~L}$ & Entire \\
\hline nec2 & LEM4 & T65 & 16 & 87 & 19 & 106 & 0.09 & - & - \\
\hline nec3 & LEM5 & T65 & 16 & 88 & 20 & 108 & 0.12 & - & - \\
\hline nec4 & LEM9 & T65 & 16 & 82 & 23 & 105 & 0.46 & $2 \mathrm{~S}$ and $2 \mathrm{~L}$ & Entire \\
\hline nec5 & LEM16 & T65 & 16 & 83 & 29 & 112 & 0.83 & $2 \mathrm{~S}$ and $2 \mathrm{~L}$ & Entire \\
\hline nec6 & LEM17 & T65 & 16 & 87 & 20 & 107 & 0.13 & $2 \mathrm{~S}$ and $2 \mathrm{~L}$ & Entire or Tip \\
\hline nec7 & LEM18 & T65 & 16 & 80 & 21 & 101 & 0.33 & $2 \mathrm{~L}$ & Entire \\
\hline nec8 & LEM24 & T65 & 19 & 71 & 23 & 94 & 0.91 & - & - \\
\hline nec 9 & LEM29 & T65 & 19 & 87 & 20 & 107 & 0.13 & $2 \mathrm{~L}$ & Entire \\
\hline nec10 & LEM36 & T65 & 19 & 154 & 49 & 203 & 0.78 & $2 \mathrm{~L}$ & Entire \\
\hline necl1 & LEM37 & T65 & 19 & 100 & 27 & 127 & 0.33 & $2 \mathrm{~L}$ & Entire or Tip \\
\hline nec12 & LEM28 & T65 & 21 & 74 & 22 & 96 & 0.64 & - & - \\
\hline nec13 & LEM43 & IR24 & 21 & 75 & 36 & 111 & 0.07 & $2 \mathrm{~L}$ & Entire \\
\hline nec14 & LEM20 & T65 & 24 & 63 & 14 & 77 & 0.17 & 4 & Entire \\
\hline nec15 & LEM25 & T65 & 35 & 80 & 20 & 100 & 0.25 & 4 & Tip \\
\hline nec16 & LEM11 & T65 & 35 & 86 & 22 & 108 & 0.27 & 4 & Tip \\
\hline nec17 & LEM41 & IR24 & 35 & 83 & 18 & 101 & 0.10 & $2 S$ & Transverse banc \\
\hline nec18 & LEM2 & T65 & 82 & 83 & 22 & 105 & 0.34 & 4 & Tip \\
\hline
\end{tabular}

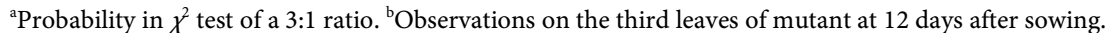




\subsection{Development of Indel Markers}

To find polymorphic indel sites in temperate japonica, we conducted de novo whole-genome sequencing of T65 by next-generation sequencing on a Roche/ 454 GS-FLX Titanium sequencer (Roche, Basel, Switzerland) and de novo assembly in GS De Novo Assembler software (Roche). The assemblies were used for BLAST similarity searches of Nipponbare pseudo-molecule build 4.0 (BLAST). Polymerase chain reaction (PCR) primers for polymorphic sites with >5-bp insertion/deletion variation were designed in Primer 3 software [33] (Supplementary Table S1, Supplementary Table S2).

\subsection{Genotyping}

Fresh leaves of $\mathrm{F}_{2}$ seedlings and their parents were collected and ground in $1 \times \mathrm{TE}$ buffer in a Multi-Beads Shocker (Yasui Kikai, Osaka, Japan), and their total genomic DNA was extracted using a modified potassium acetate method [34]. The obtained DNA was amplified by PCR with simple sequence repeat (SSR) markers [35] [36] [37] [38] [39] and indel markers (Supplementary Tables S1, Supplementary Table S2). PCR was performed in $15-\mu \mathrm{L}$ mixtures containing 50 $\mathrm{mM} \mathrm{KCl}, 10 \mathrm{mM}$ Tris-HCl (pH 9.0), $1.5 \mathrm{mM} \mathrm{MgCl} 2,200 \mu \mathrm{M}$ each dNTP, $0.2 \mu \mathrm{M}$ each primer, 0.75 units of Taq polymerase (Takara, Otsu, Japan), and approximately $5 \mathrm{ng}$ of template DNA in a GeneAmp PCR system 9700 (Applied Biosystems). PCR conditions were $95^{\circ} \mathrm{C}$ for $5 \mathrm{~min}$, followed by 35 cycles of $95^{\circ} \mathrm{C}$ for $30 \mathrm{~s}, 55^{\circ} \mathrm{C}$ for $30 \mathrm{~s}$, and $72^{\circ} \mathrm{C}$ for $30 \mathrm{~s}$. PCR products were separated in $4 \%$ agarose gels (Agarose HT, Amresco Inc., Solon, OH, USA) in 0.5× TBE buffer at $250 \mathrm{~V}$.

\subsection{Gene Mapping}

To determine the loci responsible for necrotic lethality, we used bulked segregant analysis (BSA) [40] to detect markers tightly linked to causal genes using 43 SSR and 38 indel markers polymorphic between T65 and Hinohikari, and 84 SSR and 3 indel markers polymorphic between IR24 and T65. Bulks of wild-type and mutant plants were each composed of 10 individuals from the $F_{2}$ generation. Markers showing polymorphism between the two bulks were selected and used for linkage analysis of the $\mathrm{F}_{2}$ populations based on calculation of recombination value by the maximum likelihood method [41]. The estimated recombination values were converted to map distances by Kosambi's mapping function [42] to construct linkage maps.

\subsection{ROS Accumulation}

To observe excessive accumulation of ROS in necrotic mutants, we used DAB staining to assess $\mathrm{H}_{2} \mathrm{O}_{2}$ accumulation [43]. Because necrosis was observed in third leaf of all the mutants at 12 days after sowing (DAS), third leaves of necrotic lethal mutants and wild-type plants at 12 DAS were immersed in $1 \mathrm{mg}$ $\mathrm{mL}^{-1} \mathrm{DAB}$ in distilled water and incubated for $8 \mathrm{~h}$ at $25^{\circ} \mathrm{C}$ to allow DAB uptake, with three replicates. After staining, chlorophyll was completely removed by in- 
cubation in $96 \%$ ethanol at $80^{\circ} \mathrm{C}$ for $1 \mathrm{~h}$. The leaf samples were preserved in $70 \%$ ethanol and later photographed.

\subsection{Detection of Cell Death}

Trypan blue staining was used to assess cell death as a result of necrosis [12]. In brief, fresh leaves (third leaf) were submerged in a solution of $2.5 \mathrm{mg} \cdot \mathrm{mL}^{-1}$ trypan blue, 25\% (w/v) lactic acid, 23\% (v/v) water-saturated phenol, and 25\% (v/v) glycerol in distilled water. The samples were heated in boiling water for $2 \mathrm{~min}$, placed in chloral hydrate solution ( $25 \mathrm{~g}$ in $10 \mathrm{~mL}$ of distilled water) for destaining, and preserved in $70 \%$ glycerol.

\section{Results}

\subsection{Identification of Mutants for Necrotic Lethality}

Necrotic lethality of mutant seedlings was observed in the self-pollinated progeny of the heterozygous plants in all 18 mutant lines. Wild-type and lethal necrotic seedlings segregated in a 3:1 ratio, indicating that the lethal necrosis was controlled by single recessive genes, designated necrotic lethalityl (nec1) to nec18 (Table 1).

\subsection{Phenotypic Characterization of Necrotic Mutants}

Before the third-leaf stage at 6 DAS, the phenotypes of the 18 lethal necrotic mutants were similar to those of the wild-type plants except for the necl $7 \mathrm{mu}$ tant, which had yellow-green leaves by 4 DAS (Supplementary Table S3). At the third-leaf stage, at 7 DAS, the second and third leaves of the necl mutant were pale green (Figure 1(a), and leaf-tip necrosis began in the second leaf. The necrosis spread to the entire leaf blade of the second and third leaves at 12 DAS (Figure 1(b), Supplementary Table S3), and the plant died at 16 DAS (Supplementary Table S3), during the forth-leaf stage (Figure 1(c)).

Similar pale-green discoloration and expansion of the necrosis to the entire plant were observed in all mutants except nec17. Different days to lethality (DTL) were recorded: 16 DTL in nec2, nec3, nec4, nec5, nec6, and nec7, 19 DTL in nec8, nec9, nec10, and nec11, 21 DTL in nec12 and nec13, 24 DTL in nec14, and 35 DTL in nec15, nec16, and nec17 (Table 1, Supplementary Table S3). nec18 seedlings transplanted into the paddy field at 19 DAS died at 82 DAS (Figure 1(d); Supplementary Table S3). In contrast to the other lines, the nec17 plants became yellow-green as early as 4 DAS and developed transverse necrotic bands at the second- to third-leaf stage (Figure 1(e), Figure 1(f); Supplementary Table S3). The necrosis in nec17 gradually spread to the whole plant, and plants died at 35 DAS.

\subsection{Bulked Segregant Analysis}

BSA of 14 mutant lines revealed that in the $\mathrm{F}_{2}$ population between necl and $\mathrm{Hi}$ nohikari, wild-type and mutant plants segregated in a 69:27 ratio, fitting a 3:1 


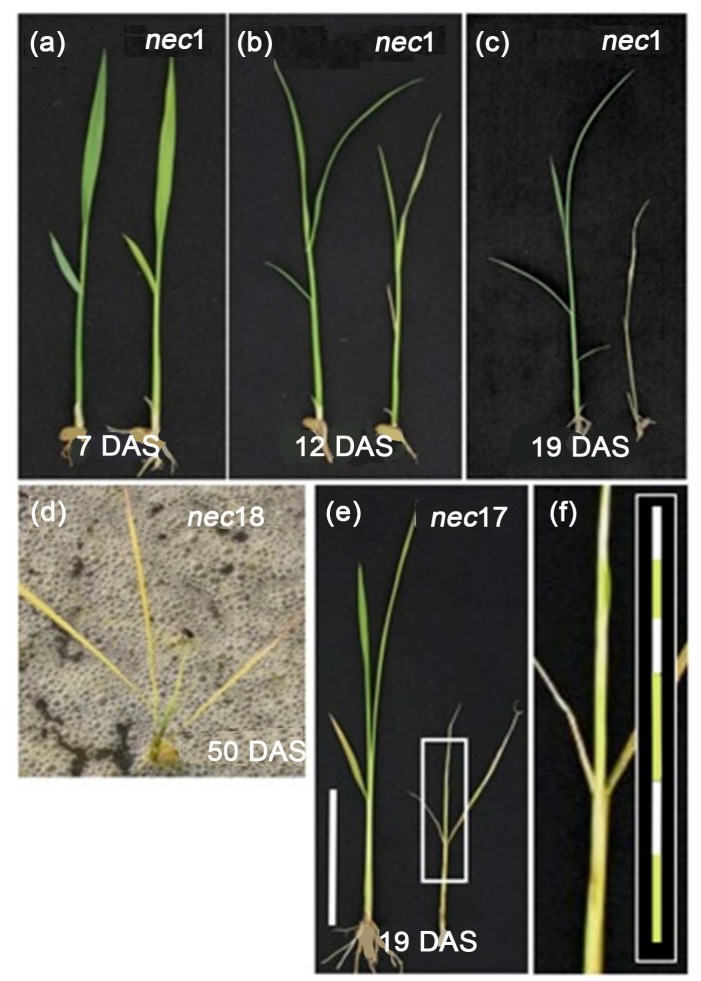

Figure 1. Three representative mutants for necrotic lethality. (a)-(c) Early necrotic lethal mutant, necl. (a) necl (right) shows pale-green discoloration in second and third leaves at 7 days after sowing (DAS) while wild-type plant (left) possesses second and third leaves with green color; (b) Leaf-tip necrosis in necl (right) spread to entire leaf blade of second leaf at 12 DAS; (c) Complete death of whole plant of necl (right) occurs at 16 - 19 DAS. (d) nec18 survived in paddy field until 82 DAS; (e)-(f) Transverse bands of necrosis in nec17. (a)-(c), (e) Left and right plants were wild types and mutants, respectively.

ratio (Table 2). At indel markers QSTS96 and QSTS109, on the long arm of chromosome $2(2 \mathrm{~L})$, the necl bulks showed an intensive band derived from T65, but the wild-type bulks showed heterozygous-like bands derived from T65 and Hinohikari alleles (Supplementary Figure S1). BSA of the other 13 mutants suggested candidate regions on the short and long arms of chromosome 2 (2S and 2L) and on the long arm of chromosome 4 (Table 1; Supplementary Table S4).

\subsection{Validation by Linkage Mapping}

Among the 14 necrotic lethal mutants in which responsible regions were identified, we conducted linkage analysis for nec1, nec13, nec16, nec17, and nec18. necl was located between QSTS103 and QSTS109 on chromosome 2L (Figure 2(b); Supplementary Table S6). nec13 was located in the same region, between QSTS96 and QSTS109 (Figure 2(c); Supplementary Table S7). nec17 was located between RM3703 and RM7082 on chromosome 2S (Figure 2(a); Supplementary Table S5). nec16 and nec18 were located on different regions of chromosome 4L: nec16 tightly linked to RM3785 and RM7051 (Figure 2(d); Supplementary Table S8), and nec18 tightly linked to QSTS141 and QSTS142 (Figure 2(e); Supplementary Table S9). 


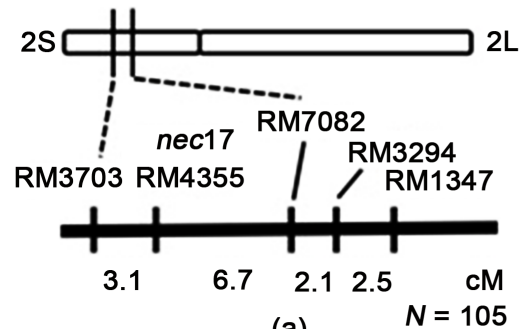

(a)

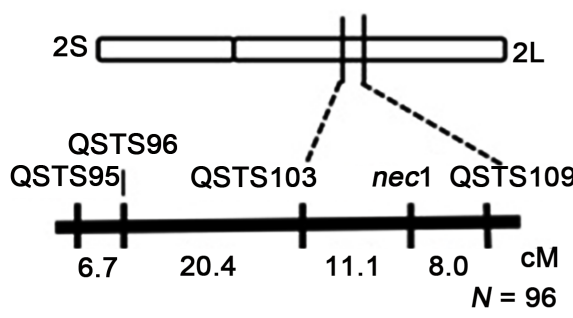

(b)

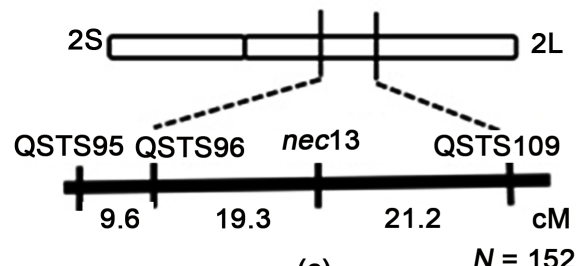

(c)

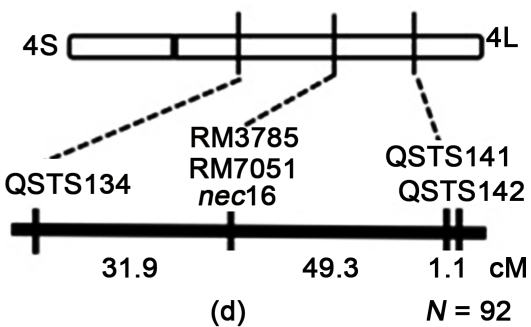

4S

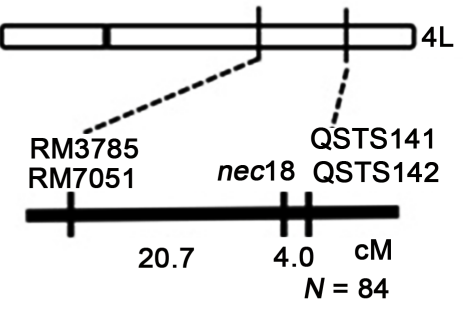

(e)

Figure 2. Linkage maps of genes for necrotic lethality in rice. (a) nec17; (b) necl; (c) nec13; (d) nec16; (e) nec18.

Table 2. Segregation of wild-type and mutant plants in $\mathrm{F}_{2}$ populations.

\begin{tabular}{|c|c|c|c|c|c|c|c|}
\hline \multicolumn{2}{|c|}{ Cross combination } & \multirow[b]{2}{*}{ Gene } & \multirow{2}{*}{$\begin{array}{c}\mathrm{F}_{1} \\
\text { phenotype }\end{array}$} & \multicolumn{4}{|c|}{ Segregation for necrotic lethality } \\
\hline Female & Male & & & $\begin{array}{l}\text { Wild } \\
\text { type }\end{array}$ & $\begin{array}{l}\text { Necrotic } \\
\text { lethality }\end{array}$ & Total & $P^{a}$ \\
\hline Hinohikari & LEM1 & necl & wild type & 69 & 27 & 96 & 0.48 \\
\hline Taichung 65 & LEM43 & nec13 & wild type & 110 & 42 & 152 & 0.45 \\
\hline Hinohikari & LEM11 & nec16 & wild type & 76 & 20 & 96 & 0.35 \\
\hline Taichung 65 & LEM41 & nec17 & wild type & 78 & 34 & 112 & 0.19 \\
\hline Hinohikari & LEM2 & nec18 & wild type & 69 & 27 & 96 & 0.48 \\
\hline
\end{tabular}

a. Probability in $\chi^{2}$ test of a 3:1 ratio.

\subsection{Allelism between nec1 and nec13}

necl and necl 3 were located in the same region on chromosome 2 L (Figure $3(\mathrm{~b})$, Figure $3(\mathrm{c})$ ). We evaluated allelism in $\mathrm{F}_{1}$ progeny of crosses between necl and nec13. If necl and nec13 are located at different loci, $\mathrm{F}_{1}$ plants derived from a cross between necl heterozygotes $(+/$ necl $)$ and necl3 heterozygotes $(+/$ necl 3$)$ would show only wild-type segregants. However, necrotic segregants were observed in $\mathrm{F}_{1}$ derived from the cross between the heterozygous plants in three replicates, indicating that necl and necl 3 are located at the same locus (Table $3)$. 

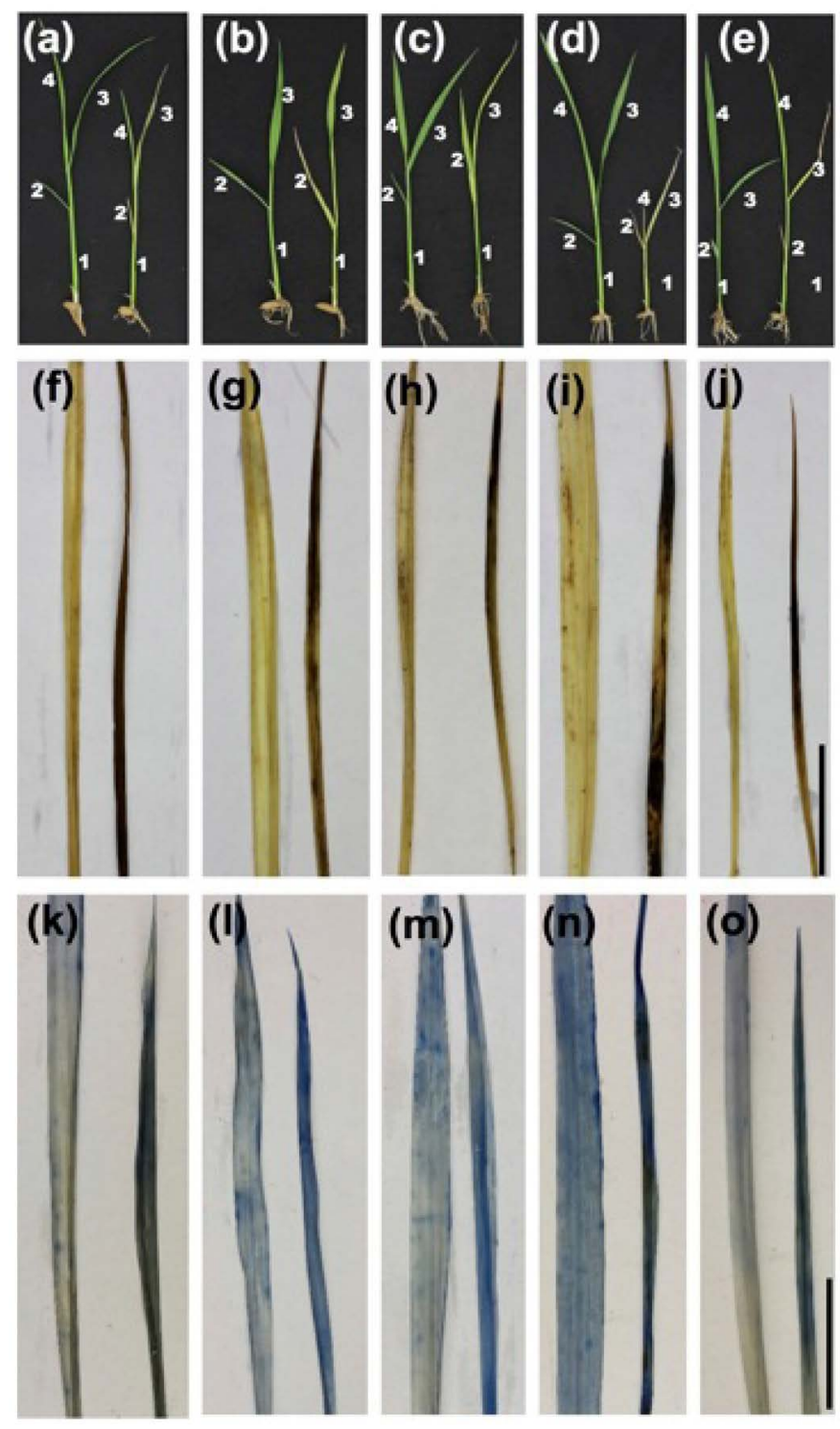

nec1

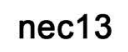

nec16

nec17

nec18

Figure 3. ROS accumulation and cell death in the third-leaves of necrotic mutants at 12 DAS. (a)-(e) Morphological features of wild type (left) and necrotic mutants (right); (f)-(o) Histochemical staining in the third leaf blade of wild type (left) and mutant (right) seedlings at 12 DAS by (f)-(j) DAB staining of $\mathrm{H}_{2} \mathrm{O}_{2}$ and (k)-(o) trypan blue staining for cell death. Bar $=5 \mathrm{~cm}$. Left and right plants were wild types and mutants, respectively.

Table 3. Segregation in $\mathrm{F}_{1}$ population derived from nec1 $\times$ nec13.

\begin{tabular}{|c|c|c|c|c|c|c|c|}
\hline \multicolumn{5}{|c|}{ Cross combination $^{\mathrm{a}}$} & \multicolumn{3}{|c|}{ Segregation for necrotic lethality in $F_{1}$} \\
\hline \multicolumn{2}{|c|}{ Female } & \multirow[t]{2}{*}{$x$} & \multicolumn{2}{|c|}{ Male } & \multirow{2}{*}{$\begin{array}{c}\text { Wild type } \\
34\end{array}$} & \multirow{2}{*}{$\begin{array}{c}\text { Necrotic lethality } \\
6\end{array}$} & \multirow{2}{*}{$\begin{array}{c}\text { Total } \\
40\end{array}$} \\
\hline LEM43-4 & $(+/$ nec13) & & LEM1-5 & $(+/$ necl $)$ & & & \\
\hline LEM43-8 & $(+/$ nec13) & & LEM1-7 & $(+/$ necl $)$ & 16 & 19 & 35 \\
\hline LEM43-12 & $(+/$ nec13) & & LEM1-12 & $(+/$ necl $)$ & 20 & 20 & 40 \\
\hline
\end{tabular}

a. Genotypes are represented in parentheses. 


\subsection{Histochemical Characterization of Lethal Necrosis}

Of the eighteen mutants, fourteen were initially characterized for their $\mathrm{H}_{2} \mathrm{O}_{2}$ accumulation of the third leaves at 12 DAS (Supplementary Figure S2). Five lethal necrotic mutants showed phenotypic differences in patterns of $\mathrm{H}_{2} \mathrm{O}_{2}$ accumulation and cell death at 12 DAS: nec1 and nec13 showed early necrotic lethality ( $<24$ DTL; Figure 3(a), Figure 3(b)), and nec16, nec17, and nec18 showed late necrotic lethality ( $>35$ DTL; Figures $3(\mathrm{c})-(\mathrm{e})$, Supplementary Figure S2; Table 1). Intense brown staining indicated $\mathrm{H}_{2} \mathrm{O}_{2}$ accumulation throughout the third leaves of necl (Figure 3(f)) and necl3 (Figure 3(g)), and in the other early necrotic lethal mutants (nec4, nec5, nec7, nec9, nec10, and nec14: Table 1; Supplementary Figure S2), as well as in the tips of the third leaves of nec16 (Figure $3(\mathrm{~h})$ ), nec1 8 (Figure $3(\mathrm{j})$ ), and nec15 (Table 1; Supplementary Figure S2). The staining pattern of the third leaves in nec6 and nec11 were not clearly classified into the entire or leaf-tip types. The third leaves of necl7 showed a transverse banding pattern of brown staining (Figure 3(i)). Trypan blue staining revealed deep blue throughout the leaf blades of nec1, nec13, nec16, nec17, and nec18 (Figures $3(\mathrm{k})-(\mathrm{o})$ ), but not in the wild-type plants. Taken together, these results suggest that excessive accumulation of $\mathrm{H}_{2} \mathrm{O}_{2}$ caused necrotic symptoms in the mutants.

\section{Discussion}

We identified 18 mutants characterized by necrotic seedling lethality. The necrotic lethality was controlled by single recessive genes which we designated necl to nec18 (Table 1). The necrosis began with leaf discoloration and necrosis formation at the leaf tip, or with transverse banding segments, during the third-leaf stage, and plants died during the fourth- to fifth-leaf stages, between 16 and 82 DAS (Figure 1; Supplementary Table S3). The initiation of necrosis at the third-leaf stage, the spread of necrosis from the leaf tip to the entire leaf, and early necrotic lethality were similar to those of lethal necrotic mutants in maize nec4, nec5, nec7, and olive-necrotic-8147 [21] [44] [45] [46].

A number of rice mutants with disease-like lesions were morphologically categorized into spotted leaf mutants (spl: [47] [48] [49], lesion mimic mutants (Imm: [27] [50], cell death and resistance mutants (cdr. [51] and zebra necrosis mutants (zn: [17] [52]. DAB staining indicated that ROS accumulation was limited to the necrotic lesions. In our study, the lethal necrotic mutants showed necrosis of the whole leaves and eventually plant death. The mutants with early necrotic lethality (nec1, nec4 - nec7, nec9 - nec11, nec13, and nec14) had rapid spread of $\mathrm{H}_{2} \mathrm{O}_{2}$ accumulation throughout the leaf at 12 DAS (Table 1; Supplementary Figure S2). Those with late necrotic lethality (nec15, nec16, nec18), in contrast, had $\mathrm{H}_{2} \mathrm{O}_{2}$ accumulation only at the leaf tip at 12 DAS.

Genetic mapping by BSA and linkage analysis revealed at least four independent loci that control necrotic lethality in 14 of the mutants (Table 1). The mutants with causal gene on chromosome $2 \mathrm{~L}$ (necl and nec13) showed early lethal- 
ity within 21 DAS, with excessive $\mathrm{H}_{2} \mathrm{O}_{2}$ accumulation throughout their leaves (Figure 2, Figure 3 and Supplementary Table S3). These phenotypes have also been reported in a necrotic mutant of maize, nec- $t$ [22]. nec- $t$ has abnormal chloroplast development and lacks photosynthetic ability. The mutants with causal genes on chromosome 4 (nec16 and nec18) had late necrotic lethality (>35 DTL) and excessive ROS production progressing from their leaf tips (Figure 2, Figure 3, Supplementary Figure S2, Supplementary Table S3). Additionally, nec1 7 on chromosome 2 S, induced late necrotic lethality (35 DTL) with distinct transverse bands (Figure 3). Rice ZEBRA-NECROSIS $(Z N)$ encodes a thylakoid-bound protein involved in the photoprotection of developing chloroplasts during early leaf development, and the $z n$ mutant shows leaves with transverse necrotic bands due to accumulation of light-induced ROS [17]. The above-mentioned mutants would be important resources for investigating mechanisms such as stress tolerance, photoprotection of chloroplasts, and nutrient deficiency in plants.

\section{Conclusion}

We identified 18 lethal necrotic mutants induced in rice by gamma-irradiation. The necrotic lethality was found to be controlled by single recessive genes designated necrotic lethalityl (necl) to nec18. Among them, five mutants were precisely mapped on the rice chromosomes: nec17 on chromosome $2 \mathrm{~S}$, necl (nec13) on chromosome $2 \mathrm{~L}$, and nec16 and nec18 on different regions of chromosome 4L. Thus at least four independent loci control necrotic lethality in rice. The histochemical analysis of these mutants at 12 DAS showed that $\mathrm{H}_{2} \mathrm{O}_{2}$ accumulated in the necrotic parts of leaves, and that cell death occurred throughout the leaf. Mutants for early necrotic lethality (necl and necl3) were characterized by the rapid spread of $\mathrm{H}_{2} \mathrm{O}_{2}$ accumulation throughout the third leaf. Mutants for late necrotic lethality (nec16, nec17 and nec18) were characterized by the incomplete spread of $\mathrm{H}_{2} \mathrm{O}_{2}$ accumulation within the third leaf.

\section{Acknowledgements}

We are grateful to Institute for Irradiation and Analysis of Quantum Radiation, Kyushu University, for the gamma-irradiation. This work was supported by the Canon foundation and partly supported by the Japan Society for the Promotion of Science for KAKENHI Grant Number JP15H04438.

\section{References}

[1] Gunter, C.C. and Egel, D.S. (2015) Illustrated Definitions of Plant Problems. https://mdc.itap.purdue.edu/item.asp?itemID=21879

[2] Cakmak, I. (1994) Activity of Ascorbate-Dependent $\mathrm{H}_{2} \mathrm{O}_{2}$-Scavenging Enzymes and Leaf Chlorosis Are Enhanced in Magnesium- and Potassium-Deficient Leaves, But Not in Phosphorous-Deficient Leaves. Journal of Experimental Botany, 45, 1259-1266. https://doi.org/10.1093/jxb/45.9.1259

[3] Chen, L., Lin, L., Cai, G., Sun, Y. Huang, T., Wang, K. and Deng, J. (2014) Identifi- 
cation of Nitrogen, Phosphorus, and Potassium Deficiencies in Rice Based on Static Scanning Technology and Hierarchical Identification Method PLoS ONE, 9, e113200. https://doi.org/10.1371/journal.pone.0113200

[4] Ding, Y.C., Chang, C., Luo, W., Wu, Y., Ren, X., Wang, P. and Xu, G. (2008) High Potassium Aggravates the Oxidative Stress Induced by Magnesium Deficiency in Rice Leaves. Pedosphere, 18, 316-327. https://doi.org/10.1016/S1002-0160(08)60021-1

[5] Mghase, J.J., Shiwachi, H., Takahashi, H. and Irie, K. (2011) Nutrient Deficiency and Their Symptoms in Upland Rice. Journal of International Society for Southeast Asian Agricultural Sciences, 59-67.

[6] Uchida, R. (2000) Essential Nutrients for Plant Growth: Nutrient Functions and Deficiency Symptoms. In: Silva, J.A. and Uchida, R., Eds., Plant Nutrient Management in Hawaiis Soils, Approaches for Tropical and Subtropical Agriculture, College of Tropical Agriculture and Human Resources, Hawaii, 31-55.

[7] Chen, C., Chen, H., Shan, J., Zhu, M., Shi, M., Gao, J. and Lin, H. (2013) Genetic and Physiological Analysis of a Novel Type of Interspecific Hybrid Weakness in Rice. Molecular Plant, 6, 176-728. https://doi.org/10.1093/mp/sss146

[8] Chen, C., Chen, H., Lin, Y., Shen, J., Shan, J., Qil, P., Shi, M., Zhu, M., Huang, X., Feng, Q., et al. (2014) A Two-Locus Interaction Causes Interspecific Hybrid Weakness in Rice. Nature Communication, 5, 3357. https://doi.org/10.1038/ncomms4357

[9] Xue, F., Guo, J., Guan, C., Wang, H., Li, A. and Kong, L. (2015) Molecular Mapping of the Hybrid Necrosis Gene NetJingY176 in Aegilops tauschii using Microsatellite Markers. Crop Journal, 3, 298-304. https://doi.org/10.1016/j.cj.2015.05.003

[10] Simmons, C., Hantke, S., Grant, S., Johal, G.S. and Briggs, S. (1998) The Maize Lethal Leaf spot1 Mutant Has Elevated Resistance to Fungal Infection at the Leaf Epidermis. Molecular Plant-Microbe Interact, 472, 1110-1118. https://doi.org/10.1094/MPMI.1998.11.11.1110

[11] Kraepiel, Y., Pedron, J., Patrit, O., Simond-Cote, E., Hermand, V. and Gijsegem, F.V. (2011) Analysis of the Plant bosl Mutant Highlights Necrosis as an Efficient Defence Mechanism during $D$. dadantiil Arabidospis thaliana Interaction. PLoS ONE, 6, e18991. https://doi.org/10.1371/journal.pone.0018991

[12] Yin, Z., Chen, J., Zeng, L., Goh, M., Leung, H., Khush, G.S. and Wang, G.L. (2000) Characterizing Rice Lesion Mimic Mutants and Identifying a Mutant with Broad-Spectrum Resistance to Rice Blast and Bacterial Blight. Molecular Plant Microbe Interact, 13, 869-876. https://doi.org/10.1094/MPMI.2000.13.8.869

[13] Delhaize, E. and Randall, P.J. (1995) Characterization of a Phosphate-Accumulator Mutant of Arabidopsis thaliana. Plant Physiology, 107, 207-213. https://doi.org/10.1104/pp.107.1.207

[14] Fujii, H., Chiou, T.J., Lin, S.I., Aung, K. and Zhu, J.K. (2005) A miRNA Involved in Phosphate-Starvation Response in Arabidopsis. Current Biology, 15, 2038-2043. https://doi.org/10.1016/j.cub.2005.10.016

[15] Hu, B., Zhu, C., Li, F., Tang, J., Wang, Y., Lin, A., Liu, L., Che, R. and Chu, C. (2011) Leaf tip necrosis1 Plays a Pivotal Role in the Regulation of Multiple Phosphate Starvation Responses in Rice. Plant Physiology, 156, 1101-1115. https://doi.org/10.1104/pp.110.170209

[16] Johal, G.S. (2007) Disease Lesion Mimic Mutants of Maize. APSnet Features. http://www.apsnet.org/publications/apsnetfeatures/Pages/MutantsofMaize.aspx

[17] Li, J., Pandeya, D., Nath, K., Zulfugarov, S.I., Yoo, S., Zhang, H., Yoo, J., Cho, S., Koh, H., Kim, D., et al. (2010) ZEBRA-NECROSIS, a Thylakoid-Bound Protein, Is 
Critical for Photoprotection of Developing Chloroplasts during Early Leaf Development. Plant Journal, 62, 713-725. https://doi.org/10.1111/j.1365-313X.2010.04183.x

[18] Sakuraba, Y., Rahman, M.L., Cho, S., Kim, Y., Koh, H., Yoo, S. and Paek, N. (2013) The Rice faded green leaf Locus Encodes Protochlorophyllide Oxidoreductase B and Is Essential for Chlorophyll Synthesis under High Light Conditions. Plant Journal, 74, 122-133. https://doi.org/10.1111/tpj.12110

[19] Gray, J., Janick-Buckner, D., Buckner, B., Close, P.S. and Johal, G.S. (2002) Light-Dependent Death of Maize $11 s 1$ Cells Is Mediated by Mature Chloroplasts. Plant Physiology, 130, 1894-1907. https://doi.org/10.1104/pp.008441

[20] Wright, S.A.I., Azarang, M. and Falk, A.B. (2007) Four Barley Mutants. Barley Genetics Newsletter, 37, 34-36.

[21] Neuffer, M.G., Coe, E.H. and Wessler, S.R. (1997) Gene Descriptions. In: Mutants of Maize, Cold Spring Harbor Laboratory, New York, 211-301.

[22] Wang, L., Han, S., Zhong, S., Wei, H., Zhang, Y., Zhao, Y. and Liu, B. (2013) Characterization and Fine Mapping of a Necrotic Leaf Mutant in Maize (Zea mays L.). Journal of Genetics and Genomics, 40, 307-314.

https://doi.org/10.1016/j.jgg.2013.04.004

[23] Ahmad, P., Sarwat, M. and Sharma, S. (2008) Reactive Oxygen Species, Antioxidants and Signaling in Plants. Journal of Plant Biology, 51, 167-173.

https://doi.org/10.1007/BF03030694

[24] Apel, K. and Hirt, H. (2004) Reactive Oxygen Species: Metabolism, Oxidative Stress, and Signal Transduction. Annual Review of Plant Biology, 55, 373-399. https://doi.org/10.1146/annurev.arplant.55.031903.141701

[25] Lorrain, S., Vailleau, F., Balague, C. and Roby, D. (2003) Lesion Mimic Mutants: Keys for Deciphering Cell Death and Defense Pathways in Plants? Trends in Plant Science, 8, 263-271. https://doi.org/10.1016/S1360-1385(03)00108-0

[26] Sun, L., Wang, Y., Liu, L., Wang, C., Gan, T., Zhang, Z., Wang, Y., Wang, D., Niu, M., Long, W., et al. (2017) Isolation and Characterization of a Spotted leaf $32 \mathrm{Mu}-$ tant with Early Leaf Senescence and Enhanced Defense Response in Rice. Science Reports, 7, Article No. 41846. https://doi.org/10.1038/srep41846

[27] Wang, J., Ye, B., Yin, J., Yuan, C., Zhou, X., Li, W., He, M., Wang, J., Chen, W., Qin, P., et al. (2015) Characterization and Fine Mapping of a Light-Dependent leaf lesion mimic mutant 1 in Rice. Plant Physiology and Biochemistry, 97, 44-51. https://doi.org/10.1016/j.plaphy.2015.09.001

[28] Xu, X., Zhang, L., Liu, B., Ye, Y. and Wu, Y. (2014) Characterization and Mapping of a Spotted Leaf Mutant in Rice (Oryza sativa). Genetics and Molecular Biology, 37, 406-413. https://doi.org/10.1590/S1415-47572014005000001

[29] Landoni, M., Francesco, A.D., Bellatti, S., Delledonne, M., Ferrarini, A., Venturini, L., Pilu, R., Bononi, M. and Tonelli, C. (2013) A Mutation in the FZL Gene of Arabidopsis Causing Alteration in Chloroplast Morphology Results in a Lesion Mimic Phenotype. Journal of Experimental Botany, 64, 4313-4328.

https://doi.org/10.1093/jxb/ert237

[30] Kamlofski, C.A., Antonelli, E., Bender, C., Jaskelioff, M, Danna, C.H., Ugalde, R. and Acevedo, A. (2007) A Lesion Mimic Mutant of Wheat with Enhanced Resistance to Leaf Rust. Plant Pathology, 56, 46-54. https://doi.org/10.1111/j.1365-3059.2006.01454.x

[31] Bethke, P.C. and Jones, R.L. (2001) Cell Death of Barley Aleurone Protoplasts Is Mediated by Reactive Oxygen Species. Plant Journal, 25, 19-29. 
https://doi.org/10.1046/j.1365-313x.2001.00930.x

[32] Yamagata Y., Doi, K., Yasui, H. and Yoshimura, A. (2007) Identification of the Mutants for Abnormal Pollen Development in Rice. Breeding Science, 57, 331-337. https://doi.org/10.1270/jsbbs.57.331

[33] Rozen, S. and Skaletsky, H.J. (2000) Primer3 on the WWW for General Users and for Biologist Programmers. In: Krawetz, S. and Misener, S., Eds., Bioinformatics Methods and Protocols. Methods in Molecular Biology, Humana Press, Totowa, 365-386.

[34] Dellaporta S.L., Wood, J. and Hicks, J.B. (1983) A Plant DNA Minipreparation Version II. Plant Molecular Biology Reporter, 1, 19-21. https://doi.org/10.1007/BF02712670

[35] Chen, X., Temnykh, S., Xu, Y., Cho, Y. and McCouch, S. (1997) Development of a Microsatellite Framework Map Providing Genome-Wide Coverage in Rice (Oryza sativa L.). Theoretical and Applied Genetics, 95, 553-567. https://doi.org/10.1007/s001220050596

[36] McCouch, S.R., Teytelman, L., Xu, Y.B., Lobos, K.B., Clare, K., Walton, M., Fu, B.Y., Maghirang, R., Li, Z.K., Xing, Y.Z., et al. (2002) Development and Mapping of 2240 SSR Markers for Rice (Oryza sativa L.). DNA Research, 9, 199-207. https://doi.org/10.1093/dnares/9.6.199

[37] Panaud, O., Chen, X. and McCouch, S. (1996) Development of Microsatellite Markers and Characterization of Simple Sequence Length Polymorphism (SSLP) in Rice (Oryza sativa L.). Molecular and General Genetics, 252, 597-607. https://doi.org/10.1007/BF02172406

[38] Temnykh, S., Park, W.D, Ayres, N., Cartinhour, S., Hauck, N., Lipovich, L., Cho, Y.G., Ishii, T. and McCouch, S.R. (2000) Mapping and Genome Organization of Microsatellite Sequences in Rice (Oryza sativa L.). Theoretical and Applied Genetics, 100, 697-712. https://doi.org/10.1007/s001220051342

[39] Temnykh, S., DeClerck, G. and Lukashova, A. (2001) Computational and Experimental Analysis of Microsatellites in Rice (Oryza sativa L.): Frequency, Length Variation, Transposon Associations, and Genetic Marker Potential. Genome Research, 11, 1441-1452. https://doi.org/10.1101/gr.184001

[40] Michelmore, R.W., Paran, I. and Kesseli, V. (1991) Identification of Markers Linked to Disease-Resistance Genes by Bulk Segregant Analysis: A Rapid Method to Detect Markers in Specific Genomic Regions by using Segregating Populations. Proceedings of the National Academy of Sciences, USA, 88, 9828-9832. https://doi.org/10.1073/pnas.88.21.9828

[41] Allard, R.W. (1956) Formulas and Tables to Facilitate the Calculation of Recombination Values in Heredity. Hilgardia, 24, 235-278. https://doi.org/10.3733/hilg.v24n10p235

[42] Kosambi, D. (1943) The Estimation of Map Distance from Recombination Values. Annals of Eugenics, 12, 172-175. https://doi.org/10.1111/j.1469-1809.1943.tb02321.x

[43] Thordal-Christensen, H., Zhang, Z., Wei, Y. and Collinge, B.D. (1997) Subcellular Localization of $\mathrm{H}_{2} \mathrm{O}_{2}$ in Plants. $\mathrm{H}_{2} \mathrm{O}_{2}$ Accumulation in Papillae and Hypersensitive Response during the Barley-Powdery Mildew Interaction. Plant Journal, 11, 1187-1194. https://doi.org/10.1046/j.1365-313X.1997.11061187.x

[44] Hoisington, D. and Neuffer, M.G. (1983) nec4, a New Necrotic Mutant on 2S. Maize Genetics Cooperation Newsletter, 57,159-160.

[45] Neuffer, M.G. and Beckett, J.B. (1987) Designation of New Recessive Mutants. Ma- 
ize Genetics Cooperation Newsletter, 61, 50.

[46] Rascio, N., Casadoro, G., Orsenigo, M. and Tonelli, C. (1981) Ultrastructural Study of an Olive Necrotic Mutant of Maize. Protoplasma, 105, 241-249.

https://doi.org/10.1007/BF01279222

[47] Mizobuchi, R., Hirabayashi, H., Kaji, R., Nishizawa, Y., Yoshimura, A., Satoh, H., Ogawa, T. and Okamoto, M. (2002) Isolation and Characterization of Rice Lesion-Mimic Mutants with Enhanced Resistance to Rice Blast and Bacterial Blight. Plant Science, 163, 345-353. https://doi.org/10.1016/S0168-9452(02)00134-6

[48] Wang, S., Lei, C., Wang, J., Ma, J. Tang, S, Wang, C., Zhao, K., Tian, P., Zhang, H., Qi1, C., et al. (2017) SPL33, Encoding an eEF1A-Like Protein, Negatively Regulates Cell Death and Defense Responses in Rice. Journal of Experimental Botany, 68, 899-913. https://doi.org/10.1093/jxb/erx001

[49] Yamanouchi, U., Yano, M., Lin, H., Ashikari, M. and Yamada, K. (2002) A Rice Spotted Leaf Gene, sp 7 , Encodes a Heat Stress Transcription Factor Protein. Proceedings of the National Academy of Sciences, USA, 99, 7530-7535.

https://doi.org/10.1073/pnas.112209199

[50] Xiao, G., Zhang, H., Lu, X. and Huang, R. (2015) Characterization and Mapping of a Novel Light-Dependent Lesion Mimic Mutant Imm6 in Rice (Oryza sativa L.). Journal of Integrative Agriculture, 9, 1687-1696.

[51] Takahashi, A., Kawasaki, T., Henmi, K., Shii, K., Kodama, O., Satoh, H. and Shimamoto, K. (1999) Lesion Mimic Mutants of Rice with Alterations in Early Signaling Events of Defense. Plant Journal, 17, 535-545. https://doi.org/10.1046/j.1365-313X.1999.00405.x

[52] Kinoshita, T. and Takamure, I. (1984) Inheritance and Linkage Relationship on Zebra Chlorosis and Zebra Necrosis in Rice. Genetical Studies on Rice Plant LXXXVIII. Journal of Faculty of Agriculture Hokkaido University, 61, 445-455. 


\section{Supplementary}

Table S1. List of markers for linkage analysis of mutants induced from Taichung 65.

\begin{tabular}{|c|c|c|c|c|c|c|}
\hline Chr. & Position $^{\mathrm{a}}$ & $\begin{array}{l}\text { Marker } \\
\text { name }\end{array}$ & $\begin{array}{l}\text { Marker } \\
\text { type }\end{array}$ & Forward primer sequence & Reverse primer sequence & Reference \\
\hline 1 & 548,641 & RM3148 & SSR & GCTTTGGTATTTGCAGGTTCACG & CTATTGCTCGAACACTTTGCTTCTCC & $\begin{array}{l}\text { McCouch } \\
\text { et al. (2002) }\end{array}$ \\
\hline 1 & $2,575,209$ & QSTS60 & Indel & AAAGCTCTGAGTGGCTTTGC & TTGGTTTGTCGATATGTTCAGC & This study \\
\hline 1 & $4,635,844$ & QSTS76 & Indel & GCGAAAACACAATGCAAAAAG & GTGTGGGGGAAGCAAGAG & This study \\
\hline 1 & $23,968,523$ & RM5 & SSR & TGCAACTTCTAGCTGCTCGA & GCATCCGATCTTGATGGG & $\begin{array}{c}\text { Panaud } \\
\text { et al. (1996) }\end{array}$ \\
\hline 1 & $26,035,809$ & RM3475 & SSR & GTCGGTTTGCCTAGTTGAGC & TTCCTCGGTGTATGGGTCTC & $\begin{array}{l}\text { McCouch } \\
\text { et al. (2002) }\end{array}$ \\
\hline 1 & $30,718,595$ & QSTS82 & Indel & TAACAACGGGGGCCTAGATG & GCCGGTGGTGAAGACGAC & This study \\
\hline 1 & $40,246,974$ & RM3520 & SSR & GAGGCTATATGCTCATGCTC & AAACCTGCAAATGCACAG & $\begin{array}{l}\text { McCouch } \\
\text { et al. (2002) }\end{array}$ \\
\hline 2 & $1,878,328$ & RM7562 & SSR & AGACATGCCAATGTGATGGC & TCGGTAGTATGGGGCTTGTC & $\begin{array}{l}\text { McCouch } \\
\text { et al. (2002) }\end{array}$ \\
\hline 2 & $4,414,049$ & RM3865 & SSR & AACCATGGACAGTTGAACAC & CTCCGACAAGAACTTCCTC & $\begin{array}{l}\text { McCouch } \\
\text { et al. (2002) }\end{array}$ \\
\hline 2 & $5,477,492$ & RM6378 & SSR & CTGATCATCTCATGCCTCCTACG & TCСATCTCCCAATATGACCAACC & $\begin{array}{l}\text { McCouch } \\
\text { et al. (2002) }\end{array}$ \\
\hline 2 & $5,852,749$ & QSTS88 & Indel & GCCATGGAAAAGAAAAGCTG & TGATCGATGGATAGCCACAC & This study \\
\hline 2 & $7,112,707$ & QSTS89 & Indel & TTTTGCACGGTTTTGTATGG & AACCGATGTCTGCATCCAAG & This study \\
\hline 2 & $9,984,944$ & QSTS90 & Indel & GAGGAGGAGGAACGAAGAGG & GTTCGCTCCTGACCTTCG & This study \\
\hline 2 & $9,998,681$ & QSTS91 & Indel & GAGGAGGAGGAACGAAGAGG & GTTCGCTCCTGACCTTCG & This study \\
\hline 2 & $10,186,627$ & RM3501 & SSR & CTACAATGATTCCATGCCTGTCC & TCCGGCTCAAGCTACAGTTAAGG & $\begin{array}{l}\text { McCouch } \\
\text { et al. (2002) }\end{array}$ \\
\hline 2 & $17,297,690$ & QSTS95 & Indel & TGAGGACAAGCATGTGAAGG & CAATGGACGCTAGTGGAACC & This study \\
\hline 2 & $18,744,542$ & QSTS96 & Indel & GCTCGTGTTCGTGCATCTATC & GCAACAACGAGAACGAGAAC & This study \\
\hline 2 & $20,751,269$ & QSTS103 & Indel & TTCGTTTCGAGTAACAAAGCAC & GTGTTAGGGAAGCACATTCG & This study \\
\hline 2 & $24,254,973$ & QSTS105 & Indel & AATATTGTAAACAAAAACTCAAAATCC & TTCTTCTCTCTCCGCCTTCC & This study \\
\hline 2 & $24,518,130$ & QSTS109 & Indel & AATATAGTTTGGTCAAAAGAACAAAAG & CGGATAATCTTGATGAGTGAACC & This study \\
\hline 2 & $24,531,197$ & QSTS110 & Indel & TGTTGGTGGTCAGTTCAACTTC & TCCCGCCTTCCATTTATTAC & This study \\
\hline 2 & $24,656,209$ & QSTS111 & Indel & CGGAGGCAGAGTAAGAATCG & CAATCCCGATTGTCGGATAC & This study \\
\hline 2 & $32,812,348$ & QSTS114 & Indel & GAAAATTTGCATTCACTCСТАCC & TTGAAAAACACGGGAATTTTATAG & This study \\
\hline 2 & $33,019,362$ & RM6733 & SSR & TCCATGTGCACAATCCAATTCC & GTGACGGCATGAGAGTGTTTGTAGG & $\begin{array}{l}\text { McCouch } \\
\text { et al. (2002) }\end{array}$ \\
\hline 2 & $33,254,219$ & QSTS115 & Indel & CGCAGTGGCTATAACCCAAG & CCGCATTAGAATCCTTCTCG & This study \\
\hline 2 & $34,676,703$ & RM213 & SSR & ATCTGTTTGCAGGGGACAAG & AGGTCTAGACGATGTCGTGA & $\begin{array}{c}\text { Chen } \\
\text { et al. (1997) }\end{array}$ \\
\hline 2 & $35,424,303$ & RM2265 & SSR & AACTGACCGTATATTAGCCA & TGACCGCCTCTATTATATTG & $\begin{array}{l}\text { McCouch } \\
\text { et al. (2002) }\end{array}$ \\
\hline
\end{tabular}




\section{Continued}

\begin{tabular}{|c|c|c|c|c|c|c|}
\hline 2 & $35,450,160$ & RM3850 & SSR & AAGTTGAGAATGAGGGACAA & TTCGGAAGTGAAAAGGTAAT & $\begin{array}{l}\text { McCouch } \\
\text { et al. (2002) }\end{array}$ \\
\hline 2 & $35,729,140$ & RM3274 & SSR & GCTGCTGCTGCTACAGTTTG & GCGAGCTCCAGCATTTAAAC & $\begin{array}{l}\text { McCouch } \\
\text { et al. (2002) }\end{array}$ \\
\hline 2 & $35,160,161$ & RM208 & SSR & TCTGCAAGCCTTGTCTGATG & TAAGTCGATCATTGTGTGGACC & $\begin{array}{c}\text { Chen et al. } \\
\quad(1997)\end{array}$ \\
\hline 3 & $8,170,550$ & RM5639 & SSR & GGAAGAACAGAGTTGCTCGG & GTGCCATTTATTTCCGTCCC & $\begin{array}{l}\text { McCouch } \\
\text { et al. (2002) }\end{array}$ \\
\hline 3 & $1,437,206$ & RM3372 & SSR & GAGCGACCAAAGAATCCAAG & CCACGGGGAGCTGATGAAG & $\begin{array}{l}\text { McCouch } \\
\text { et al. (2002) }\end{array}$ \\
\hline 3 & $5,971,990$ & RM3467 & SSR & ATAATGGCAGGGTTGTCTCG & CTCGGTGAGCCTCCTACAAC & $\begin{array}{l}\text { McCouch } \\
\text { et al. (2002) }\end{array}$ \\
\hline 3 & $16,285,889$ & QSTS125 & Indel & TTGAATCAATCACACATCTTATTCAG & TCCATATGGCCCAACATAAAC & This study \\
\hline 3 & $28,479,745$ & RM1350 & SSR & CGCCCTAGTAGATAGGTAATTG & AAATCAGCAAGAAAGCTCTG & $\begin{array}{l}\text { McCouch } \\
\text { et al. (2002) }\end{array}$ \\
\hline 4 & $24,222,895$ & RM3785 & SSR & ACCTTTTCTTGGCTTGAGGG & GCTTTTGCTACTTTTGGGGG & $\begin{array}{l}\text { McCouch } \\
\text { et al. (2002) }\end{array}$ \\
\hline 4 & $24,277,170$ & RM7051 & SSR & CTCGATGAGCTTGGCGTC & TTCAGTGTTCATCGCCTCTG & $\begin{array}{l}\text { McCouch } \\
\text { et al. (2002) }\end{array}$ \\
\hline 4 & $5,275,427$ & QSTS132 & Indel & TTTCGATGCTGTCAATCTACG & TCGATCCATCCACTTCCTTC & This study \\
\hline 4 & $13,164,721$ & QSTS134 & Indel & CTTGTATTGCGTGCAGGATG & TTGGCTTCAATGCATACACC & This study \\
\hline 4 & $31,466,041$ & QSTS141 & Indel & CCATGCATCCTCCTGTTCC & CTGTTGATGGGTCCCAATTC & This study \\
\hline 4 & $31,485,856$ & QSTS142 & Indel & AGCTTTTTGGGTGATGTTGG & GGATGCTCTTTCTCCACCAC & This study \\
\hline 5 & $9,320,757$ & RM6836 & SSR & TTGTTGTATACCTCATCGAC & AGGGTAAGACGTTTAACTTG & $\begin{array}{l}\text { McCouch } \\
\text { et al. (2002) }\end{array}$ \\
\hline 5 & 82,104 & RM3529 & SSR & CGCGCCACCTCGATATATAC & GCTCAGGTTAACCAAGGTGG & $\begin{array}{l}\text { McCouch } \\
\text { et al. (2002) }\end{array}$ \\
\hline 5 & $4,311,860$ & QSTS145 & Indel & GAGACGGTCCCAACAAAGAC & CGTTTTAAACCATCCTTAGACG & This study \\
\hline 5 & $17,292,400$ & QSTS152 & Indel & GAAACTCGGCCAATTGTAAC & TGACATGGCTGTCTTCAACC & This study \\
\hline 6 & $3,168,368$ & RM204 & SSR & GTGACTGACTTGGTCATAGGG & GCTAGCCATGCTCTCGTACC & $\begin{array}{c}\text { Chen } \\
\text { et al. (1997) }\end{array}$ \\
\hline 6 & $10,151,590$ & QSTS157 & Indel & TGCTGTCATGCCAACTTACC & AAATGGCAGCATCTTCAAGC & This study \\
\hline 6 & $23,054,814$ & QSTS171 & Indel & TGAAAACCGTGTCACTGTCC & GGGGCTCTAATCACCTCCAG & This study \\
\hline 6 & $25,612,879$ & RM6395 & SSR & GGCTTCGGCTTCTGAACTAGC & CGACTAAGCAGCAGTAACAATCTCG & $\begin{array}{l}\text { McCouch } \\
\text { et al. (2002) }\end{array}$ \\
\hline 6 & $28,563,631$ & RM3307 & SSR & CAGTGCTCTCGAACATGGAG & CTGCATTGTAAACGGTCGAG & $\begin{array}{l}\text { McCouch } \\
\text { et al. (2002) }\end{array}$ \\
\hline 7 & $1,186,748$ & RM6697 & SSR & GCAAGATCCAGTCGATTTGG & ATAACATGAGCATCTCCCCG & $\begin{array}{l}\text { McCouch } \\
\text { et al. (2002) }\end{array}$ \\
\hline 7 & $23,596,003$ & RM5847 & SSR & TGAGATGAGAGATAGACTCC & AACAGATGAAGGCTATTTTA & $\begin{array}{l}\text { McCouch } \\
\text { et al. (2002) }\end{array}$ \\
\hline 7 & $4,692,609$ & RM6872 & SSR & CACCACGATATCCACCTCTAGC & CCTAGGATGAACACTGATGATGG & $\begin{array}{l}\text { McCouch } \\
\text { et al. (2002) }\end{array}$ \\
\hline
\end{tabular}




\section{Continued}

\begin{tabular}{|c|c|c|c|c|c|c|}
\hline 7 & $11,713,561$ & QSTS176 & Indel & GTGGCAGCTTGAGAGCATTC & TTTAATCCAAGCTTAGGCAACC & This study \\
\hline 7 & $13,552,392$ & QSTS180 & Indel & GGAGCTCGTACAGAAAAATCG & CCGGAGGTATATTCCTTGTTTG & This study \\
\hline 7 & $17,831,145$ & QSTS182 & Indel & GGCAATGGAACTTTTTGATTTG & ATGCACTTTCTGTCTCAGTTTG & This study \\
\hline 7 & $21,243,983$ & QSTS191 & Indel & CAGTTTGGCACTGGCCTATC & GCATTTCACTCAAGCAATGG & This study \\
\hline 7 & $28,894,378$ & RM1306 & SSR & TGCCAATTACCTTCCCGTAC & TGCTCCGTATTGCTGCTATG & $\begin{array}{l}\text { McCouch } \\
\text { et al. (2002) }\end{array}$ \\
\hline 8 & $20,645,571$ & RM223 & SSR & GAGTGAGCTTGGGCTGAAAC & GAAGGCAAGTCTTGGCACTG & $\begin{array}{c}\text { Chen } \\
\text { et al. (1997) }\end{array}$ \\
\hline 8 & $26,294,879$ & QSTS215 & Indel & TCССТTAACTTGTCAACAAATCC & GCCACGTCAGCTAAAACCTC & This study \\
\hline 8 & $27,898,042$ & RM3155 & SSR & GAAAAGGACAGGGGAAAAGC & GATCGTTCGTGTTCGTGTTG & $\begin{array}{l}\text { McCouch } \\
\text { et al. (2002) }\end{array}$ \\
\hline 9 & $5,048,789$ & QSTS222 & Indel & CAACCAGCGAAACATACTGC & ACGGGAGGAAGATGACCAC & This study \\
\hline 9 & $11,045,262$ & QSTS227 & Indel & TTTTTGCTTCTCACCCATTC & TTGCATGAACAGAGGTTTGC & This study \\
\hline 9 & $12,583,087$ & QSTS228 & Indel & ATATCATTCCGGTGCCTACC & GTGCGCATGTGTGTGTACTG & This study \\
\hline 9 & $14,644,334$ & QSTS229 & Indel & AGTGGATGGATGGATGGATG & CGTCGTCTCTTCCGTTTTTC & This study \\
\hline 9 & $20,246,472$ & RM3808 & SSR & CGTTAGCGAAACGAACAGTG & CAGTGGCTCGGTAATCGC & $\begin{array}{l}\text { McCouch } \\
\text { et al. (2002) }\end{array}$ \\
\hline 9 & $17,054,142$ & RM3600 & SSR & TGCCCACACATGATGAGC & AACGGGCAAGAGATCTTCTG & $\begin{array}{l}\text { McCouch } \\
\text { et al. (2002) }\end{array}$ \\
\hline 10 & $2,522,494$ & QSTS237 & Indel & GACCAGAGACTGCCCCATC & TCACTTCAAGTCTGTGGTTTCAG & This study \\
\hline 10 & $22,133,218$ & QSTS248 & Indel & TGCAATTGACTACTACTCCAAGG & TCAAACAAACAATCGTGAAGC & This study \\
\hline 10 & $17,490,576$ & RM6704 & SSR & AATCGAATCTGGATATCTTG & CTTCTACCTAGCTACCGAGA & $\begin{array}{l}\text { McCouch } \\
\text { et al. (2002) }\end{array}$ \\
\hline 10 & $15,903,727$ & RM5304 & SSR & CATCTTGAATCCTCCTTCGACTCC & GGCAGCGATAGCAGGAAGAGG & $\begin{array}{l}\text { McCouch } \\
\text { et al. (2002) }\end{array}$ \\
\hline 11 & 794,611 & QSTS250 & Indel & CGTTGGATAATTAATGGAGATCG & CACAAGCACCAAACCCAAC & This study \\
\hline 11 & $4,484,051$ & QSTS255 & Indel & CATTGCTACGAGGCACAATC & CCGCGCACGTAGGTATATG & This study \\
\hline 11 & $7,007,889$ & QSTS263 & Indel & ATAAAATCCGGCGAGACAAG & GAAGCGAGTGCTCCTAGCTC & This study \\
\hline 11 & $21,626,773$ & RM206 & SSR & CCCATGCGTTTAACTATTCT & CGTTCCATCGATCCGTATGG & $\begin{array}{l}\text { Chen } \\
\text { et al. }(1997)\end{array}$ \\
\hline 11 & $28,173,902$ & RM144 & SSR & CATGTTGTGCTTGTCCTACTGC & $\begin{array}{c}\text { AGCTAGAGGAGATCAGATGGTAGTG } \\
\text { C }\end{array}$ & $\begin{array}{l}\text { Temnykh } \\
\text { et al. }(2000)\end{array}$ \\
\hline 12 & 905,092 & RM1080 & SSR & AGAGCCCTCGTAAGCCAAAG & GGTCGTGAATCTCCTCCAAG & $\begin{array}{l}\text { McCouch } \\
\text { et al. (2002) }\end{array}$ \\
\hline 12 & $4,919,671$ & RM3455 & SSR & TGAATCCACACTCGCAGATC & GCCAGTCCACGATTGGTC & $\begin{array}{l}\text { McCouch } \\
\text { et al. }(2002)\end{array}$ \\
\hline 12 & $25,036,187$ & RM3739 & SSR & AGTTGCGCAGCTAATCGATC & AAGATCCAACGGGTTCTGTG & $\begin{array}{l}\text { McCouch } \\
\text { et al. }(2002)\end{array}$ \\
\hline 12 & $8,828,165$ & RM101 & SSR & GTGAATGGTCAAGTGACTTAGGTGGC & ACACAACATGTTCCCTCCCATGC & $\begin{array}{l}\text { Temnykh } \\
\text { et al. }(2000)\end{array}$ \\
\hline 12 & $19,156,079$ & RM1246 & SSR & AGCTCGATCCCCTAGCTCTC & TTGGAGAAGGTCACCTGCC & $\begin{array}{l}\text { McCouch } \\
\text { et al. }(2002)\end{array}$ \\
\hline 12 & $25,067,717$ & RM5715 & SSR & GCAGAAGAGAGAAATGAAAG & CTTGTCTACGTAGCATGACA & $\begin{array}{l}\text { McCouch } \\
\text { et al. (2002) }\end{array}$ \\
\hline
\end{tabular}

${ }^{\text {a }}$ Position on rice pseudo-molecule build 4.0. 
Table S2. List of markers for linkage analysis of the mutants induced from IR24.

\begin{tabular}{|c|c|c|c|c|c|c|}
\hline Chr. & Position $^{\mathrm{a}}$ & $\begin{array}{c}\text { Marker } \\
\text { name }\end{array}$ & $\begin{array}{l}\text { Marker } \\
\text { type }\end{array}$ & Forward primer sequence & Reverse primer sequence & Reference \\
\hline 1 & $6,273,454$ & RM8111 & SSR & AGGTAACTAAGCTAGGTGTT & TAGGTACAGTAATACCAAGC & $\begin{array}{l}\text { McCouch } \\
\text { et al. (2002) }\end{array}$ \\
\hline 1 & $8,915,941$ & RM8083 & SSR & $\begin{array}{l}\text { GATGTGCAAATTATCA } \\
\text { TGTGTTTTGTGAGG }\end{array}$ & $\begin{array}{l}\text { ATAGTAGGCCCACA } \\
\text { CCTGACAGGTTGTA }\end{array}$ & $\begin{array}{l}\text { McCouch } \\
\text { et al. (2002) }\end{array}$ \\
\hline 1 & $9,938,600$ & RM8046 & SSR & $\begin{array}{l}\text { AGTACGATTTCTGT } \\
\text { CAGCGTTGCTTAGT }\end{array}$ & $\begin{array}{c}\text { GGATGAAAGTTGATGG } \\
\text { ATGATCTACTTGTT }\end{array}$ & $\begin{array}{l}\text { McCouch } \\
\text { et al. (2002) }\end{array}$ \\
\hline 1 & $10,703,670$ & RM23 & SSR & CATTGGAGTGGAGGCTGG & GTCAGGCTTCTGCCATTCTC & $\begin{array}{c}\text { Chen } \\
\text { et al. (1997) }\end{array}$ \\
\hline 1 & $18,973,690$ & RM24 & SSR & GAAGTGTGATCACTGTAACC & TACAGTGGACGGCGAAGTCG & $\begin{array}{c}\text { Chen } \\
\text { et al. (1997) }\end{array}$ \\
\hline 1 & $23,968,523$ & RM5 & SSR & TGCAACTTCTAGCTGCTCGA & GCATCCGATCTTGATGGG & $\begin{array}{c}\text { Panaud } \\
\text { et al. (1996) }\end{array}$ \\
\hline 1 & $30,732,007$ & RM128 & SSR & AGCTTGGGTGATTTCTTGGAAGCG & ACGACGAGGAGTCGCCGTGCAG & $\begin{array}{l}\text { Temnykh } \\
\text { et al. (2000) }\end{array}$ \\
\hline 1 & $38,002,959$ & RM6333 & SSR & AGAGAAGACACGGTGGATGG & CAAACTCCTCATTTCGCTCC & $\begin{array}{l}\text { McCouch } \\
\text { et al. (2002) }\end{array}$ \\
\hline 1 & $40,161,142$ & RM104 & SSR & GGAAGAGGAGAGAAAGATGTGTGTCG & TCAACAGACACACCGCCACCGC & $\begin{array}{l}\text { Temnykh } \\
\text { et al. (2000) }\end{array}$ \\
\hline 1 & $42,919,515$ & RM8136 & SSR & ATGTAAGCTAGGTAGAGCTG & GCGTACGTACGTAAGTAATA & $\begin{array}{l}\text { McCouch } \\
\text { et al. (2002) }\end{array}$ \\
\hline 2 & 346,475 & RM6800 & SSR & CAAGCCTACATGGCCTAGACTCC & ATCCATGATCCATCATCCATGC & $\begin{array}{l}\text { McCouch } \\
\text { et al. (2002) }\end{array}$ \\
\hline 2 & $1,083,895$ & RM154 & SSR & ACCCTCTCCGCCTCGCCTCCTC & CTCCTCCTCCTGCGACCGCTCC & $\begin{array}{l}\text { Temnykh } \\
\text { et al. (2000) }\end{array}$ \\
\hline 2 & $1,660,838$ & RM7033 & SSR & AGAATAACTCCAGCCCACACTGG & GCGGTGATTTCTGATGACATTCC & $\begin{array}{l}\text { McCouch } \\
\text { et al. (2002) }\end{array}$ \\
\hline 2 & $3,863,789$ & RM3703 & SSR & GAGAGAGAGGGAAGGGAAGG & GCTCCCCGACATTTAAACTG & $\begin{array}{l}\text { McCouch } \\
\text { et al. (2002) }\end{array}$ \\
\hline 2 & $4,264,267$ & RM4355 & SSR & GGGATGAGAGTAGAAGGCA & TATATGGCAAGCCTAGCG & $\begin{array}{l}\text { McCouch } \\
\text { et al. (2002) }\end{array}$ \\
\hline 2 & $5,100,932$ & RM7082 & SSR & TCTCCAACAGCAGCGAGG & GACCCGGCCTTCTACCTAAC & $\begin{array}{l}\text { McCouch } \\
\text { et al. (2002) }\end{array}$ \\
\hline 2 & $5,204,941$ & RM3294 & SSR & TTACACACACTACGGACGCG & CCTGGTGGTACCTCTCTTAATC & $\begin{array}{l}\text { McCouch } \\
\text { et al. (2002) }\end{array}$ \\
\hline 2 & $5,314,413$ & RM1347 & SSR & AACAAATTAAACTGCCAAG & GTCTTATCATCAGAACTGGA & $\begin{array}{l}\text { McCouch } \\
\text { et al. (2002) }\end{array}$ \\
\hline 2 & $6,732,637$ & RM5897 & SSR & GGCATCTTCCССТСТСТCTC & CCAACCCAAACCAGTCTACC & $\begin{array}{l}\text { McCouch } \\
\text { et al. (2002) }\end{array}$ \\
\hline 2 & $7,541,911$ & RM3505 & SSR & GATGAGGTGGGACGACGAC & TCTTCACAGTGACGAAACCG & $\begin{array}{l}\text { McCouch } \\
\text { et al. (2002) }\end{array}$ \\
\hline 2 & $8,759,533$ & RM71 & SSR & CTAGAGGCGAAAACGAGATG & GGGTGGGCGAGGTAATAATG & $\begin{array}{l}\text { Temnykh } \\
\text { et al. }(2000)\end{array}$ \\
\hline
\end{tabular}




\section{Continued}

\begin{tabular}{|c|c|c|c|c|c|c|}
\hline 2 & $8,980,509$ & RM5699 & SSR & ATCGTTTCGCATATGTTT & ATCGGTAAAAGATGAGCC & $\begin{array}{l}\text { McCouch } \\
\text { et al. (2002) }\end{array}$ \\
\hline 2 & $10,186,627$ & RM3501 & SSR & TCCTAGTGCATCAGCACAGC & GTCCGTTTCAGCAAGCAAAC & $\begin{array}{l}\text { McCouch } \\
\text { et al. (2002) }\end{array}$ \\
\hline 2 & $15,999,806$ & RM5812 & SSR & CGCTGACATCTTGCCCTC & GTAGGACCCACGTGTCATCC & $\begin{array}{l}\text { McCouch } \\
\text { et al. (2002) }\end{array}$ \\
\hline 2 & $17,297,690$ & QSTS95 & Indel & TGAGGACAAGCATGTGAAGG & CAATGGACGCTAGTGGAACC & This study \\
\hline 2 & $18,744,542$ & QSTS96 & Indel & GCTCGTGTTCGTGCATCTATC & GCAACAACGAGAACGAGAAC & This study \\
\hline 2 & $17,946,057$ & RM6611 & SSR & CACACACGCACGGTTAGATC & СТССТСАССТСТТССССТТС & $\begin{array}{l}\text { McCouch } \\
\text { et al. (2002) }\end{array}$ \\
\hline 2 & $18,169,378$ & RM6844 & SSR & CAGAGCAGGAACAGATGCTG & GTCCAAGAAAGGCACGAGAG & $\begin{array}{l}\text { McCouch } \\
\text { et al. (2002) }\end{array}$ \\
\hline 2 & $19,361,410$ & RM341 & SSR & CAAGAAACCTCAATCCGAGC & СТCСТCCCGATCCСAATC & $\begin{array}{l}\text { Temnykh } \\
\text { et al. }(2000)\end{array}$ \\
\hline 2 & $20,996,870$ & RM6023 & SSR & AAGGAAGCAGCGATGTGAAG & GAGCTAGAGATCACCTGGCG & $\begin{array}{l}\text { McCouch } \\
\text { et al. }(2002)\end{array}$ \\
\hline 2 & $24,518,130$ & QSTS109 & Indel & $\begin{array}{l}\text { AATATAGTTTGGTC } \\
\text { AAAAGAACAAAAG }\end{array}$ & CGGATAATCTTGATGAGTGAACC & This study \\
\hline 2 & $26,260,867$ & RM3730 & SSR & TGCGAGTATCTTCAAGGCAG & ATTGAGGGGGCTAATCATCC & $\begin{array}{l}\text { McCouch } \\
\text { et al. (2002) }\end{array}$ \\
\hline 2 & $27,172,434$ & RM5470 & SSR & CATGGATTGTCTGGGCCTAG & AAGACATACCCTGAGTGTGGG & $\begin{array}{l}\text { McCouch } \\
\text { et al. (2002) }\end{array}$ \\
\hline 2 & $28,291,970$ & RM5631 & SSR & CGTCCAAGAAATATTGCAGT & GTGAGACAGAATCCTTACGC & $\begin{array}{l}\text { McCouch } \\
\text { et al. (2002) }\end{array}$ \\
\hline 2 & $29,604,207$ & RM6 & SSR & GTCСССТССАСССААТTC & TCGTCTACTGTTGGCTGCAC & $\begin{array}{c}\text { Panaud } \\
\text { et al. (1996) }\end{array}$ \\
\hline 2 & $29,655,949$ & RM318 & SSR & GTACGGAAAACATGGTAGGAAG & TCGAGGGAAGGATCTGGTC & $\begin{array}{l}\text { Temnykh } \\
\text { et al. }(2000)\end{array}$ \\
\hline 2 & $34,709,116$ & RM3789 & SSR & TTCCCGAATTAAGCAGATATA & CTGTAGACCATTGACTGGTG & $\begin{array}{l}\text { McCouch } \\
\text { et al. (2002) }\end{array}$ \\
\hline 3 & $8,170,550$ & RM5639 & SSR & GGAAGAACAGAGTTGCTCGG & GTGCCATTTATTTCCGTCCC & $\begin{array}{l}\text { McCouch } \\
\text { et al. (2002) }\end{array}$ \\
\hline 3 & $12,901,320$ & RM5551 & SSR & GACTAGTCCGGCCGTACATG & AGTTTCTTGTGTGACGCGTG & $\begin{array}{l}\text { McCouch } \\
\text { et al. (2002) }\end{array}$ \\
\hline 3 & $22,203,310$ & RM6832 & SSR & GTTGTAAATGCCTGAGTGC & AAAGAGCTAAACCGCTAGG & $\begin{array}{l}\text { McCouch } \\
\text { et al. (2002) }\end{array}$ \\
\hline 3 & $26,547,224$ & RM347 & SSR & CACCTCAAACTTTTAACCGCAC & TCCGGCAAGGGATACGGCGG & $\begin{array}{l}\text { Temnykh } \\
\text { et al. (2000) }\end{array}$ \\
\hline 3 & $31,185,979$ & RM448 & SSR & TCTGATCTTGATGCAGGCAC & TCTCCCGATTTGGACAGATC & $\begin{array}{l}\text { Temnykh } \\
\text { et al. (2001) }\end{array}$ \\
\hline 3 & $33,589,206$ & RM7000 & SSR & СССТTСТTTTCAACTGAATA & TTGTAACAATGAACTCGTTC & $\begin{array}{l}\text { McCouch } \\
\text { et al. (2002) }\end{array}$ \\
\hline 4 & $19,913,395$ & RM6679 & SSR & TTTAGGCCGTAAGAGCGAAC & GAATTTGAGTAGCTGGCTCC & $\begin{array}{l}\text { McCouch } \\
\text { et al. (2002) }\end{array}$ \\
\hline
\end{tabular}




\section{Continued}

\begin{tabular}{|c|c|c|c|c|c|c|}
\hline 4 & $28,733,259$ & RM303 & SSR & GCATGGCCAAATATTAAAGG & GGTTGGAAATAGAAGTTCGGT & $\begin{array}{l}\text { Temnykh } \\
\text { et al. (2000) }\end{array}$ \\
\hline 4 & $32,869,409$ & RM348 & SSR & CCGCTACTAATAGCAGAGAG & GGAGCTTTGTTCTTGCGAAC & $\begin{array}{l}\text { Temnykh } \\
\text { et al. }(2000)\end{array}$ \\
\hline 5 & 456,843 & RM3796 & SSR & ATTAGCCTTTAATTCCACTG & ATACAAACAAACAGCTTGTG & $\begin{array}{l}\text { McCouch } \\
\text { et al. (2002) }\end{array}$ \\
\hline 5 & $2,084,750$ & RM4710 & SSR & AACTGGTTACAAAGACATGG & TCATCTACATATGGGGACAC & $\begin{array}{l}\text { McCouch } \\
\text { et al. (2002) }\end{array}$ \\
\hline 5 & $8,799,525$ & RM6082 & SSR & AACCCTAGAATCGGCGCTG & CACCGATGACAACGAGGAC & $\begin{array}{l}\text { McCouch } \\
\text { et al. (2002) }\end{array}$ \\
\hline 5 & $19,107,688$ & RM163 & SSR & ATCCATGTGCGCCTTTATGAGGA & CGCTACСТCСТTCACTTACTAGT & $\begin{array}{l}\text { McCouch } \\
\text { et al. (2002) }\end{array}$ \\
\hline 5 & $22,817,739$ & RM3870 & SSR & TACATCTCCGGCGTTTACAC & CCAAGGTTGAAACAGGAAGC & $\begin{array}{l}\text { McCouch } \\
\text { et al. (2002) }\end{array}$ \\
\hline 5 & $26,712,707$ & RM2357 & SSR & CCTCCGTTTCACAATGTAAC & CTGATGCTACCAGAATCCTC & $\begin{array}{l}\text { McCouch } \\
\text { et al. (2002) }\end{array}$ \\
\hline 5 & $29,161,099$ & RM6346 & SSR & ACTTTGATCGATCAGCCACC & AGGTGGTGGAGATGAAGCAG & $\begin{array}{l}\text { McCouch } \\
\text { et al. (2002) }\end{array}$ \\
\hline 6 & $3,168,380$ & RM8125 & SSR & CTCGTACCATCGGCTGT & $\begin{array}{c}\text { AACTTACTGTGACT } \\
\text { GACTTGGTCA }\end{array}$ & $\begin{array}{l}\text { McCouch } \\
\text { et al. (2002) }\end{array}$ \\
\hline 6 & $5,108,560$ & RM111 & SSR & CACAACCTTTGAGCACCGGGTC & ACGCCTGCAGCTTGATCACCGG & $\begin{array}{l}\text { Temnykh } \\
\text { et al. }(2000)\end{array}$ \\
\hline 6 & $9,320,757$ & RM6836 & SSR & TTGTTGTATACCTCATCGAC & AGGGTAAGACGTTTAACTTG & $\begin{array}{l}\text { McCouch } \\
\text { et al. (2002) }\end{array}$ \\
\hline 6 & $19,152,497$ & RM3 & SSR & ACACTGTAGCGGCCACTG & ССТCСАCTGCTCCACATCTT & $\begin{array}{c}\text { Panaud } \\
\text { et al. (1996) }\end{array}$ \\
\hline 6 & $28,216,527$ & RM340 & SSR & GGTAAATGGACAATCCTATGGC & GACAAATATAAGGGCAGTGTGC & $\begin{array}{l}\text { Temnykh } \\
\text { et al. }(2000)\end{array}$ \\
\hline 6 & $30,349,942$ & RM345 & SSR & ATTGGTAGCTCAATGCAAGC & GTGCAACAACCCCACATG & $\begin{array}{l}\text { Temnykh } \\
\text { et al. }(2000)\end{array}$ \\
\hline 7 & $2,711,818$ & RM427 & SSR & TCACTAGCTCTGCCCTGACC & TGATGAGAGTTGGTTGCGAG & $\begin{array}{l}\text { Temnykh } \\
\text { et al. (2001) }\end{array}$ \\
\hline 7 & $3,174,334$ & RM5711 & SSR & GTCCATGCATCCATCTCTAG & ACGGAAGGAATACGTCTGTA & $\begin{array}{l}\text { McCouch } \\
\text { et al. (2002) }\end{array}$ \\
\hline 7 & $5,762,184$ & RM6728 & SSR & GGGTATGTGTCGCTATTTTA & GAAATCTGGAATTTTCCCTA & $\begin{array}{l}\text { McCouch } \\
\text { et al. (2002) }\end{array}$ \\
\hline 7 & $17,132,877$ & RM3795 & SSR & CATTTGCATGGAGAGGATAG & TCATCTTCATTTCATTTCACC & $\begin{array}{l}\text { McCouch } \\
\text { et al. (2002) }\end{array}$ \\
\hline 7 & $22,135,427$ & RM10 & SSR & TTGTCAAGAGGAGGCATCG & CAGAATGGGAAATGGGTCC & $\begin{array}{c}\text { Panaud } \\
\text { et al. (1996) }\end{array}$ \\
\hline 7 & $25,599,925$ & RM18 & SSR & TTCССТCTCATGAGCTCCAT & GAGTGCCTGGCGCTGTAC & $\begin{array}{c}\text { Panaud } \\
\text { et al. (1996) }\end{array}$ \\
\hline 7 & $28,871,445$ & RM1362 & SSR & AAACAGGCCCTTAGTGCATG & CTACCATGGCGGCTTATGTC & $\begin{array}{l}\text { McCouch } \\
\text { et al. (2002) }\end{array}$ \\
\hline
\end{tabular}




\section{Continued}

\begin{tabular}{|c|c|c|c|c|c|c|}
\hline 8 & $12,288,044$ & RM331 & SSR & GAACCAGAGGACAAAAATGC & CATCATACATTTGCAGCCAG & $\begin{array}{l}\text { Temnykh } \\
\text { et al. (2000) }\end{array}$ \\
\hline 8 & $19,002,002$ & RM4815 & SSR & AGTAAATTTCACAAAACTTC & GTGATACAATGCATTAAATA & $\begin{array}{l}\text { McCouch } \\
\text { et al. (2002) }\end{array}$ \\
\hline 8 & $20,971,647$ & RM5887 & SSR & CAATGATGGTGGTGAAAATC & GCTCATCTAGAAATCACCGA & $\begin{array}{l}\text { McCouch } \\
\text { et al. (2002) }\end{array}$ \\
\hline 8 & $26,140,941$ & RM5493 & SSR & GCAGGACACAGTCACACAGG & AGATTCTTTCACCGGTGACG & $\begin{array}{l}\text { McCouch } \\
\text { et al. (2002) }\end{array}$ \\
\hline 8 & $27,834,839$ & RM3496 & SSR & CGCTGAAAATACTGAATTGA & AGATGCATTTATTCCGAAAG & $\begin{array}{l}\text { McCouch } \\
\text { et al. (2002) }\end{array}$ \\
\hline 9 & $7,259,847$ & RM5526 & SSR & TCAGCCTGGCCTCTCTTATC & ATGATCCTCСACССАСТAGC & $\begin{array}{l}\text { McCouch } \\
\text { et al. (2002) }\end{array}$ \\
\hline 9 & $11,694,729$ & RM3769 & SSR & TGCATGCTTCGTTCAGCTAG & GTCTCCGAGCTCCTCAGGTC & $\begin{array}{l}\text { McCouch } \\
\text { et al. (2002) }\end{array}$ \\
\hline 9 & $14,313,180$ & RM5657 & SSR & TATGTGCATTTGTAAGGTGA & GCTTTAGATTATTGAGCGAG & $\begin{array}{l}\text { McCouch } \\
\text { et al. (2002) }\end{array}$ \\
\hline 9 & $16,818,078$ & RM7175 & SSR & ACAGTAAACGTGGTGCCTCC & AGAAGTAGCCTCGAGGACCC & $\begin{array}{l}\text { McCouch } \\
\text { et al. (2002) }\end{array}$ \\
\hline 9 & $21,906,494$ & RM7306 & SSR & TCGATCCAACGCTAGCTACC & CGGAATGGGGAGGAGATC & $\begin{array}{l}\text { McCouch } \\
\text { et al. (2002) }\end{array}$ \\
\hline 10 & $17,490,576$ & RM6704 & SSR & AATCGAATCTGGATATCTTG & CTTCTACCTAGCTACCGAGA & $\begin{array}{l}\text { McCouch } \\
\text { et al. (2002) }\end{array}$ \\
\hline 10 & $21,122,837$ & RM3451 & SSR & CGGCGAGATAACAATTCTCC & GCGTGATGATATGGTATCGG & $\begin{array}{l}\text { McCouch } \\
\text { et al. (2002) }\end{array}$ \\
\hline 10 & $21,982,081$ & RM496 & SSR & GACATGCGAACAACGACATC & GCTGCGGCGCTGTTATAC & $\begin{array}{l}\text { Temnykh } \\
\text { et al. (2001) }\end{array}$ \\
\hline 11 & $2,327,413$ & RM7557 & SSR & GTGTACTGCCATGAAAGGCC & GAAGTGCCTTTGCAGGAGAG & $\begin{array}{l}\text { McCouch } \\
\text { et al. (2002) }\end{array}$ \\
\hline 11 & $8,908,333$ & RM202 & SSR & CAGATTGGAGATGAAGTCCTCC & CCAGCAAGCATGTCAATGTA & $\begin{array}{c}\text { Chen } \\
\text { et al. (1997) }\end{array}$ \\
\hline 11 & $23,829,201$ & RM7277 & SSR & GCTGAACGTTTCAATATGTA & GTTTGTAGGGAGTTTAATGG & $\begin{array}{l}\text { McCouch } \\
\text { et al. (2002) }\end{array}$ \\
\hline 11 & $26,668,576$ & RM6688 & SSR & GTGCCGTTTAATACGTAGAC & AAGGAAACTTTTTTTTGCTC & $\begin{array}{l}\text { McCouch } \\
\text { et al. (2002) }\end{array}$ \\
\hline 12 & $2,181,948$ & RM7315 & SSR & CACAAAGGCGTGTGGGTTAG & GAGTCACGGGATGTTGCC & $\begin{array}{l}\text { McCouch } \\
\text { et al. (2002) }\end{array}$ \\
\hline 12 & $7,566,745$ & RM2529 & SSR & CATTAAAATCAGTGGGACTG & AGGCATTTCCTGATATGATC & $\begin{array}{l}\text { McCouch } \\
\text { et al. (2002) }\end{array}$ \\
\hline 12 & $19,156,079$ & RM1246 & SSR & AGCTCGATCCCCTAGCTCTC & TTGGAGAAGGTCACCTGCC & $\begin{array}{l}\text { McCouch } \\
\text { et al. (2002) }\end{array}$ \\
\hline 12 & $21,282,401$ & RM1986 & SSR & TAACGGAGGGAGTAGTTTTC & GAACCTACATATCGAGAGCA & $\begin{array}{l}\text { McCouch } \\
\text { et al. (2002) }\end{array}$ \\
\hline 12 & $27,420,423$ & RM2197 & SSR & ACTGAGAACTTTAATCATCG & GAACAACTTTGAAGAGAAAC & $\begin{array}{l}\text { McCouch } \\
\text { et al. (2002) }\end{array}$ \\
\hline
\end{tabular}

${ }^{\text {a} P o s i t i o n ~ o n ~ r i c e ~ p s e u d o-m o l e c u l e ~ b u i l d ~ 4.0 . ~}$ 
Table S3. Phenotypic characterization of necrotic mutants in rice (2016).

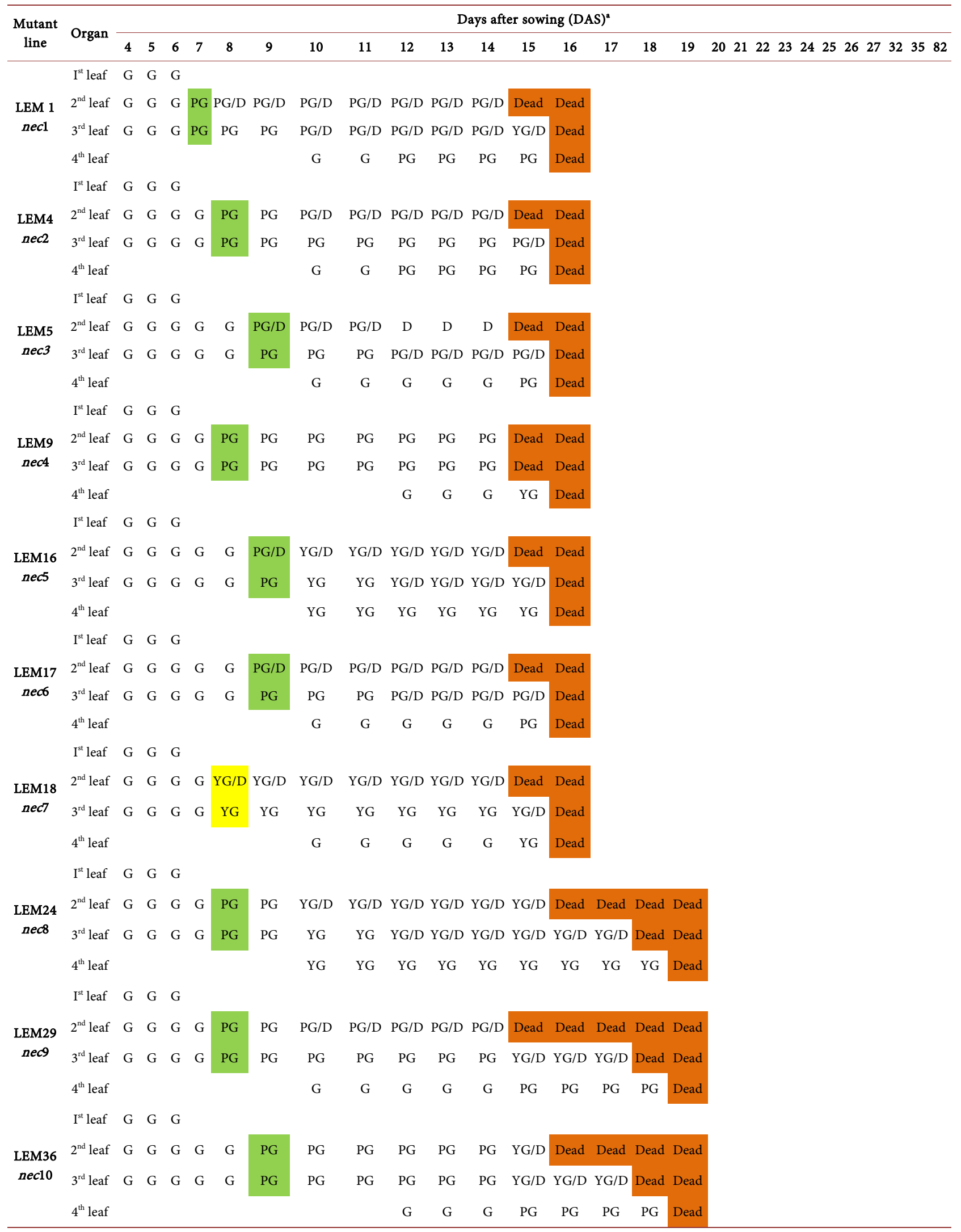

${ }^{\mathrm{a}} \mathrm{G}, \mathrm{PG}, \mathrm{YG}, \mathrm{D}$ and Dead represent green, pale-green, yellow green, drying and dead, respectively. 


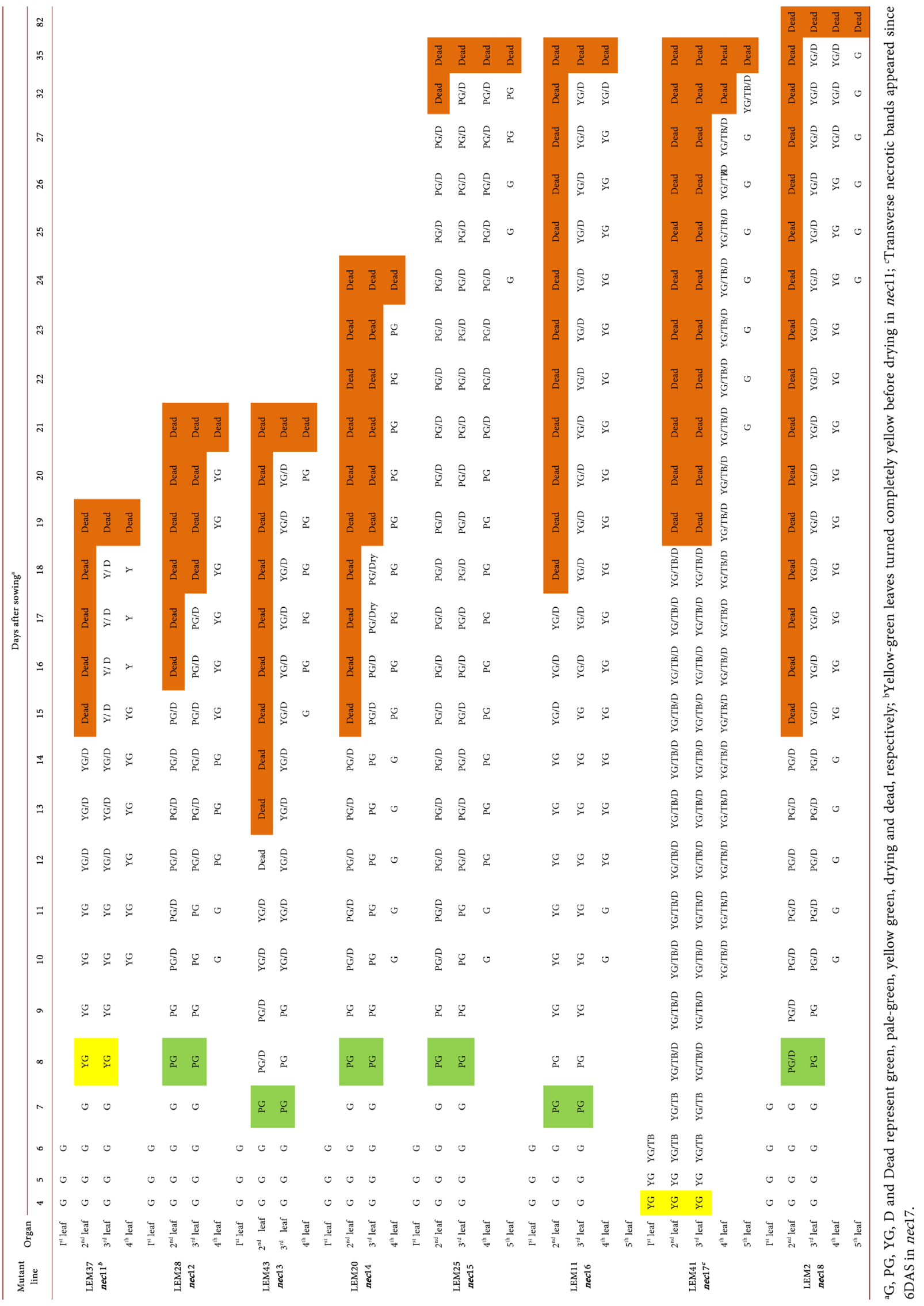


Table S4. Inferred markers linked to causal genes by bulked segregant analysis.

\begin{tabular}{cccc}
\hline Gene & Original cultivar & Chromosomal locations & Markers positively suggested \\
\hline nec1 & Taichung 65 & 2L & QSTS91, QSTS95, QSTS96, QSTS103, QSTS109 \\
nec4 & Taichung 65 & 2L and 2S & QSTS89, QSTS91, QSTS95, QSTS96, QSTS103, QSTS109, RM3850, \\
nec5 & Taichung 65 & 2L and 2S & RM7562, RM3865, QSTS88, QSTS89, QSTS91, RM3850 \\
nec6 & Taichung 65 & 2L and 2S & QSTS88, QSTS89 \\
nec7 & Taichung 65 & 2L & QSTS89, QSTS91, QSTS95, QSTS96, QSTS103 \\
nec9 & Taichung 65 & 2L & QSTS91, QSTS95, QSTS96, QSTS103, QSTS109, QSTS114 \\
nec10 & Taichung 65 & 2L & QSTS91, QSTS95, QSTS96, QSTS103, QSTS109 \\
nec11 & Taichung 65 & 2L & QSTS91, QSTS95, QSTS96, QSTS103, QSTS109 \\
nec13 & IR24 & 2L & QSTS95, QSTS96, QSTS109 \\
nec14 & Taichung 65 & $4 \mathrm{~L}$ & RM3785, RM7051, QSTS141, QSTS142 \\
nec15 & Taichung 65 & $4 \mathrm{~L}$ & RM3785, RM7051, QSTS141, QSTS142 \\
nec16 & Taichung 65 & $4 \mathrm{~L}$ & QSTS134, RM3785, RM7051, QSTS141, QSTS142 \\
nec17 & IR24 & 2S & RM3703, RM4355 \\
nec18 & Taichung 65 & $4 \mathrm{~L}$ & QSTS134, QSTS141, QSTS142
\end{tabular}

${ }^{a}$ Marker positions are indicated in Supplementary Table 1 and Table 2 for the mutants induced from Taichung 65 and IR24, respectively.

Table S5. Linkage analysis of nec17 and DNA markers on chromosome 2.

\begin{tabular}{|c|c|c|c|c|c|c|c|c|c|c|c|c|c|}
\hline \multicolumn{2}{|c|}{ Gene pair ${ }^{\mathrm{a}}$} & \multicolumn{10}{|c|}{ Number of plants } & \multirow{2}{*}{$\begin{array}{l}\text { Recombination } \\
\text { value }(\%)\end{array}$} & \multirow{2}{*}{$\begin{array}{c}\text { Map } \\
\text { distance (cM) }\end{array}$} \\
\hline $\mathrm{A}(\mathrm{a})$ & $\mathrm{B}(\mathrm{b})$ & $\mathrm{AABB}$ & $\mathrm{AABb}$ & AAbb & $\mathrm{AaBB}$ & $\mathrm{AaBb}$ & Aabb & $\mathrm{aaBB}$ & $\mathrm{aaBb}$ & aabb & Total & & \\
\hline nec17 & RM3703 & 26 & 44 & 1 & - & - & - & 1 & 0 & 26 & 98 & 3.1 & 3.1 \\
\hline nec17 & RM4355 & 17 & 57 & 0 & _- & _ & _- & 0 & 0 & 29 & 103 & 0.0 & 0.0 \\
\hline nec17 & RM7082 & 20 & 50 & 2 & - & - & - & 0 & 5 & 23 & 100 & 6.7 & 6.7 \\
\hline nec17 & RM3294 & 21 & 53 & 1 & - & - & - & 0 & 6 & 20 & 101 & 6.9 & 6.9 \\
\hline nec17 & RM1347 & 18 & 54 & 3 & - & - & - & 0 & 7 & 22 & 104 & 9.2 & 9.3 \\
\hline RM3703 & RM4355 & 16 & 8 & 1 & 1 & 43 & 0 & 0 & 1 & 26 & 96 & 6.5 & 6.5 \\
\hline RM3703 & RM7082 & 16 & 8 & 1 & 4 & 36 & 2 & 0 & 6 & 20 & 93 & 12.6 & 12.9 \\
\hline RM3703 & RM3294 & 17 & 9 & 1 & 4 & 38 & 1 & 0 & 7 & 17 & 94 & 13.1 & 13.5 \\
\hline RM3703 & RM1347 & 14 & 11 & 1 & 4 & 37 & 3 & 0 & 8 & 19 & 97 & 15.7 & 16.3 \\
\hline RM4355 & RM7082 & 15 & 1 & 0 & 3 & 49 & 2 & 0 & 5 & 23 & 98 & 5.8 & 5.8 \\
\hline RM4355 & RM3294 & 16 & 1 & 0 & 3 & 52 & 1 & 0 & 6 & 20 & 99 & 5.8 & 5.8 \\
\hline RM4355 & RM1347 & 14 & 2 & 0 & 3 & 51 & 3 & 0 & 7 & 22 & 102 & 7.7 & 7.8 \\
\hline RM7082 & RM3294 & 20 & 0 & 0 & 0 & 53 & 1 & 0 & 3 & 19 & 96 & 2.1 & 2.1 \\
\hline RM7082 & RM1347 & 17 & 2 & 0 & 0 & 54 & 1 & 0 & 2 & 23 & 99 & 2.6 & 2.6 \\
\hline RM3294 & RM1347 & 18 & 2 & 0 & 0 & 57 & 2 & 0 & 1 & 20 & 100 & 2.5 & 2.5 \\
\hline
\end{tabular}

${ }^{\mathrm{a}}$ Capital and lower-case letters represent the Taichung 65 alleles and IR24 alleles, respectively. 
Table S6. Linkage analysis of nec1 and DNA markers on chromosome 2.

\begin{tabular}{|c|c|c|c|c|c|c|c|c|c|c|c|c|c|}
\hline \multicolumn{2}{|c|}{ Gene pair ${ }^{\mathrm{a}}$} & \multicolumn{10}{|c|}{ Number of plants } & \multirow{2}{*}{$\begin{array}{l}\text { Recombination } \\
\text { value (\%) }\end{array}$} & \multirow{2}{*}{$\begin{array}{c}\text { Map } \\
\text { distance (cM) }\end{array}$} \\
\hline $\mathrm{A}(\mathrm{a})$ & $\mathrm{B}(\mathrm{b})$ & $\mathrm{AABB}$ & $\mathrm{AABb}$ & AAbb & $\mathrm{AaBB}$ & $\mathrm{AaBb}$ & Aabb & aaBB & $\mathrm{aaBb}$ & aabb & Total & & \\
\hline necl & QSTS95 & 26 & 33 & 10 & - & - & - & 5 & 7 & 14 & 95 & 30.1 & 34.8 \\
\hline necl & QSTS96 & 27 & 33 & 8 & - & - & - & 4 & 10 & 12 & 94 & 29.7 & 34.2 \\
\hline necl & QSTS103 & 20 & 44 & 5 & - & - & - & 0 & 6 & 21 & 96 & 11.1 & 11.3 \\
\hline necl & QSTS109 & 18 & 47 & 3 & _ & _ & _- & 0 & 5 & 22 & 95 & 8.0 & 8.0 \\
\hline necl & QSTS110 & 18 & 47 & 4 & - & - & - & 1 & 4 & 22 & 96 & 10.0 & 10.1 \\
\hline QSTS95 & QSTS96 & 28 & 1 & 1 & 1 & 36 & 3 & 0 & 5 & 18 & 93 & 6.6 & 6.7 \\
\hline QSTS95 & QSTS103 & 17 & 11 & 3 & 7 & 30 & 3 & 0 & 8 & 16 & 95 & 20.4 & 21.6 \\
\hline QSTS95 & QSTS109 & 11 & 14 & 5 & 8 & 25 & 7 & 0 & 12 & 12 & 94 & 31.9 & 37.8 \\
\hline QSTS95 & QSTS110 & 11 & 13 & 7 & 8 & 25 & 7 & 1 & 12 & 11 & 95 & 35.6 & 44.7 \\
\hline QSTS96 & QSTS103 & 18 & 11 & 2 & 10 & 32 & 1 & 0 & 7 & 13 & 94 & 19.4 & 20.5 \\
\hline QSTS96 & QSTS109 & 12 & 14 & 4 & 10 & 28 & 5 & 0 & 10 & 10 & 93 & 29.9 & 34.5 \\
\hline QSTS96 & QSTS110 & 12 & 13 & 6 & 10 & 28 & 5 & 1 & 10 & 9 & 94 & 33.8 & 41.1 \\
\hline QSTS103 & QSTS109 & 13 & 6 & 1 & 6 & 38 & 5 & 0 & 8 & 18 & 95 & 15.5 & 16.0 \\
\hline QSTS103 & QSTS110 & 13 & 6 & 1 & 8 & 37 & 5 & 1 & 8 & 17 & 96 & 17.9 & 18.7 \\
\hline QSTS109 & QSTS110 & 18 & 0 & 0 & 1 & 50 & 1 & 0 & 1 & 24 & 95 & 1.6 & 1.6 \\
\hline
\end{tabular}

${ }^{a}$ Capital and lower-case letters represent the Hinohikari and Taichung 65 alleles, respectively.

Table S7. Linkage analysis of nec13 and DNA markers on chromosome 2.

\begin{tabular}{|c|c|c|c|c|c|c|c|c|c|c|c|c|c|}
\hline \multicolumn{2}{|c|}{ Gene pair ${ }^{\mathrm{a}}$} & \multicolumn{10}{|c|}{ Number of plants } & \multirow{2}{*}{$\begin{array}{c}\text { Recombination } \\
\text { value (\%) }\end{array}$} & \multirow{2}{*}{$\begin{array}{c}\text { Map } \\
\text { distance }(\mathrm{cM})\end{array}$} \\
\hline $\mathrm{A}(\mathrm{a})$ & $\mathrm{B}(\mathrm{b})$ & AABB & $\mathrm{AABb}$ & AAbb & $\mathrm{AaBB}$ & $\mathrm{AaBb}$ & Aabb & aaBB & $\mathrm{aaBb}$ & aabb & Total & & \\
\hline nec13 & QSTS95 & 31 & 60 & 19 & - & - & - & 2 & 10 & 29 & 151 & 21.6 & 23.2 \\
\hline nec13 & QSTS96 & 30 & 66 & 13 & - & - & - & 1 & 13 & 28 & 151 & 18.4 & 19.3 \\
\hline nec13 & QSTS109 & 33 & 61 & 14 & - & - & - & 5 & 6 & 31 & 150 & 20.0 & 21.2 \\
\hline QSTS95 & QSTS96 & 26 & 5 & 2 & 5 & 63 & 2 & 0 & 11 & 36 & 150 & 9.5 & 9.6 \\
\hline QSTS95 & QSTS109 & 19 & 12 & 2 & 15 & 36 & 17 & 4 & 19 & 25 & 149 & 28.5 & 32.3 \\
\hline QSTS96 & QSTS109 & 21 & 8 & 2 & 13 & 44 & 20 & 4 & 14 & 23 & 149 & 25.6 & 28.3 \\
\hline
\end{tabular}

${ }^{a}$ Capital and lower-case letters represent the Taichung 65 alleles and IR24 alleles, respectively.

Table S8. Linkage analysis of nec16 and DNA markers on chromosome 4.

\begin{tabular}{|c|c|c|c|c|c|c|c|c|c|c|c|c|c|}
\hline \multicolumn{2}{|c|}{ Gene pair ${ }^{\mathrm{a}}$} & \multicolumn{10}{|c|}{ Number of plants } & \multirow{2}{*}{$\begin{array}{l}\text { Recombination } \\
\text { value (\%) }\end{array}$} & \multirow{2}{*}{$\begin{array}{c}\text { Map } \\
\text { distance (cM) }\end{array}$} \\
\hline $\mathrm{A}(\mathrm{a})$ & $\mathrm{B}(\mathrm{b})$ & $\mathrm{AABB}$ & $\mathrm{AABb}$ & AAbb & $\mathrm{AaBB}$ & $\mathrm{AaBb}$ & Aabb & $\mathrm{aaBB}$ & $\mathrm{aaBb}$ & aabb & Total & & \\
\hline nec16 & QSTS132 & 28 & 27 & 16 & - & - & - & 2 & 8 & 9 & 90 & 34.2 & 41.8 \\
\hline nec16 & QSTS134 & 28 & 27 & 11 & - & - & - & 1 & 8 & 9 & 84 & 28.2 & 31.9 \\
\hline nec16 & RM3785 & 21 & 50 & 0 & - & - & - & 0 & 0 & 19 & 90 & 0.0 & 0.0 \\
\hline nec16 & RM7051 & 21 & 52 & 0 & - & - & - & 0 & 0 & 19 & 92 & 0.0 & 0.0 \\
\hline nec16 & QSTS141 & 18 & 37 & 17 & - & - & - & 3 & 6 & 9 & 90 & 37.8 & 49.3 \\
\hline nec16 & QSTS142 & 19 & 38 & 16 & - & - & - & 3 & 7 & 9 & 92 & 36.9 & 47.3 \\
\hline QSTS132 & QSTS134 & 26 & 4 & 0 & 1 & 27 & 2 & 2 & 4 & 16 & 82 & 9.5 & 9.6 \\
\hline
\end{tabular}




\section{Continued}

\begin{tabular}{llllllllllllll}
\hline QSTS132 & RM3785 & 9 & 18 & 2 & 6 & 21 & 8 & 6 & 9 & 9 & 88 & 39.5 & 53.7 \\
QSTS132 & RM7051 & 9 & 19 & 2 & 6 & 21 & 8 & 6 & 10 & 9 & 90 & 39.9 & 54.7 \\
QSTS132 & QSTS141 & 7 & 14 & 8 & 7 & 13 & 14 & 7 & 14 & 4 & 88 & 53.2 & \\
QSTS132 & QSTS142 & 7 & 15 & 8 & 8 & 14 & 13 & 7 & 14 & 4 & 90 & 53.2 & 33.6 \\
QSTS134 & RM3785 & 9 & 18 & 1 & 6 & 20 & 8 & 2 & 9 & 9 & 82 & 40.8 \\
QSTS134 & RM7051 & 9 & 19 & 1 & 6 & 21 & 8 & 2 & 9 & 9 & 84 & 33.7 & 40.9 \\
QSTS134 & QSTS141 & 9 & 13 & 7 & 7 & 12 & 14 & 3 & 14 & 3 & 82 & 48.3 & 101.1 \\
QSTS134 & QSTS142 & 9 & 13 & 7 & 7 & 14 & 14 & 3 & 14 & 3 & 84 & 48.2 & 100.2 \\
RM3785 & RM7051 & 21 & 0 & 0 & 0 & 50 & 0 & 0 & 0 & 19 & 90 & 0.0 & 0.0 \\
RM3785 & QSTS141 & 12 & 7 & 2 & 6 & 28 & 15 & 3 & 6 & 9 & 88 & 29.9 & 34.5 \\
RM3785 & QSTS142 & 12 & 7 & 2 & 7 & 29 & 14 & 3 & 7 & 9 & 90 & 30.0 & 34.7 \\
RM7051 & QSTS141 & 12 & 7 & 2 & 6 & 30 & 15 & 3 & 6 & 9 & 90 & 29.4 & 33.7 \\
RM7051 & QSTS142 & 12 & 7 & 2 & 7 & 31 & 14 & 3 & 7 & 9 & 92 & 29.5 & 3.1 \\
QSTS141 & QSTS142 & 21 & 0 & 0 & 0 & 43 & 0 & 1 & 0 & 25 & 90 & 1.1 \\
\hline
\end{tabular}

${ }^{a}$ Capital and lower-case letters represent the Hinohikari and Taichung 65 alleles, respectively.

Table S9. Linkage analysis of nec18 and DNA markers on chromosome 4.

\begin{tabular}{|c|c|c|c|c|c|c|c|c|c|c|c|c|c|}
\hline \multicolumn{2}{|c|}{ Gene pair ${ }^{\mathrm{a}}$} & \multicolumn{10}{|c|}{ Number of plants } & \multirow{2}{*}{$\begin{array}{l}\text { Recombination } \\
\text { value }(\%)\end{array}$} & \multirow{2}{*}{$\begin{array}{c}\text { Map } \\
\text { distance }(\mathrm{cM})\end{array}$} \\
\hline $\mathrm{A}(\mathrm{a})$ & $\mathrm{B}(\mathrm{b})$ & $\mathrm{AABB}$ & $\mathrm{AABb}$ & AAbb & $\mathrm{AaBB}$ & $\mathrm{AaBb}$ & Aabb & $\mathrm{aaBB}$ & $\mathrm{aaBb}$ & aabb & Total & & \\
\hline nec18 & QSTS132 & 16 & 33 & 11 & _- & - & - & 5 & 10 & 7 & 82 & 43.0 & 64.6 \\
\hline nec18 & QSTS134 & 11 & 30 & 18 & - & - & - & 4 & 10 & 7 & 80 & 48.8 & 109.7 \\
\hline nec18 & RM3785 & 22 & 36 & 1 & - & - & - & 0 & 12 & 9 & 80 & 18.0 & 18.8 \\
\hline nec18 & RM7051 & 23 & 37 & 1 & - & - & - & 0 & 14 & 9 & 84 & 19.6 & 20.7 \\
\hline nec 18 & QSTS141 & 30 & 30 & 0 & - & - & - & 0 & 3 & 20 & 83 & 4.0 & 4.0 \\
\hline nec18 & QSTS142 & 30 & 31 & 0 & - & - & - & 0 & 3 & 19 & 83 & 4.0 & 4.0 \\
\hline QSTS132 & QSTS134 & 10 & 6 & 3 & 5 & 28 & 9 & 0 & 4 & 13 & 78 & 21.8 & 23.4 \\
\hline QSTS132 & RM3785 & 7 & 10 & 2 & 15 & 22 & 5 & 0 & 15 & 2 & 78 & 40.2 & 55.4 \\
\hline QSTS132 & RM7051 & 8 & 11 & 2 & 15 & 23 & 5 & 0 & 16 & 2 & 82 & 39.5 & 53.5 \\
\hline QSTS132 & QSTS141 & 8 & 9 & 4 & 16 & 16 & 10 & 5 & 8 & 5 & 81 & 45.9 & 79.0 \\
\hline QSTS132 & QSTS142 & 8 & 9 & 4 & 16 & 17 & 9 & 5 & 8 & 5 & 81 & 45.8 & 78.0 \\
\hline QSTS134 & RM3785 & 9 & 4 & 1 & 9 & 23 & 7 & 4 & 17 & 2 & 76 & 40.5 & 56.4 \\
\hline QSTS134 & RM7051 & 9 & 5 & 1 & 10 & 23 & 7 & 4 & 19 & 2 & 80 & 41.5 & 59.4 \\
\hline QSTS134 & QSTS141 & 4 & 8 & 3 & 15 & 14 & 10 & 10 & 10 & 5 & 79 & 53.9 & \\
\hline QSTS134 & QSTS142 & 4 & 8 & 3 & 15 & 15 & 9 & 10 & 10 & 5 & 79 & 54.1 & \\
\hline RM3785 & RM7051 & 22 & 0 & 0 & 0 & 48 & 0 & 0 & 0 & 10 & 80 & 0.0 & 0.0 \\
\hline RM3785 & QSTS141 & 14 & 7 & 0 & 14 & 25 & 9 & 0 & 1 & 9 & 79 & 21.9 & 23.5 \\
\hline RM3785 & QSTS142 & 14 & 8 & 0 & 14 & 25 & 9 & 0 & 1 & 8 & 79 & 22.8 & 24.6 \\
\hline RM7051 & QSTS141 & 15 & 7 & 0 & 15 & 25 & 11 & 0 & 1 & 9 & 83 & 22.9 & 24.8 \\
\hline RM7051 & QSTS142 & 15 & 8 & 0 & 15 & 25 & 11 & 0 & 1 & 8 & 83 & 23.7 & 25.8 \\
\hline QSTS141 & QSTS142 & 30 & 0 & 0 & 0 & 33 & 0 & 0 & 0 & 19 & 82 & 0.0 & 0.0 \\
\hline
\end{tabular}

${ }^{a}$ Capital and lower-case letters represent the Hinohikari and Taichung 65 alleles, respectively. 


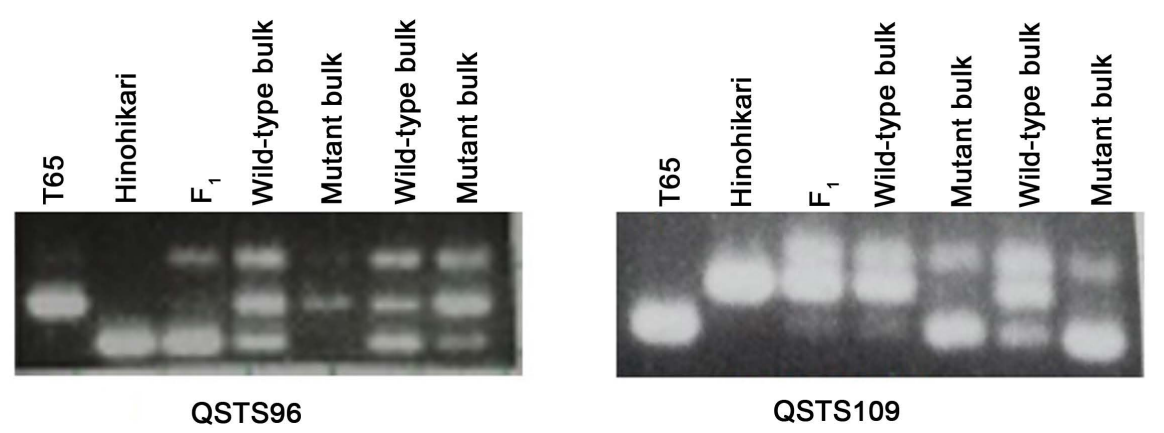

Figure S1. Detection of DNA markers linked to nec1 locus on chromosome 2 by bulked segregant analysis.
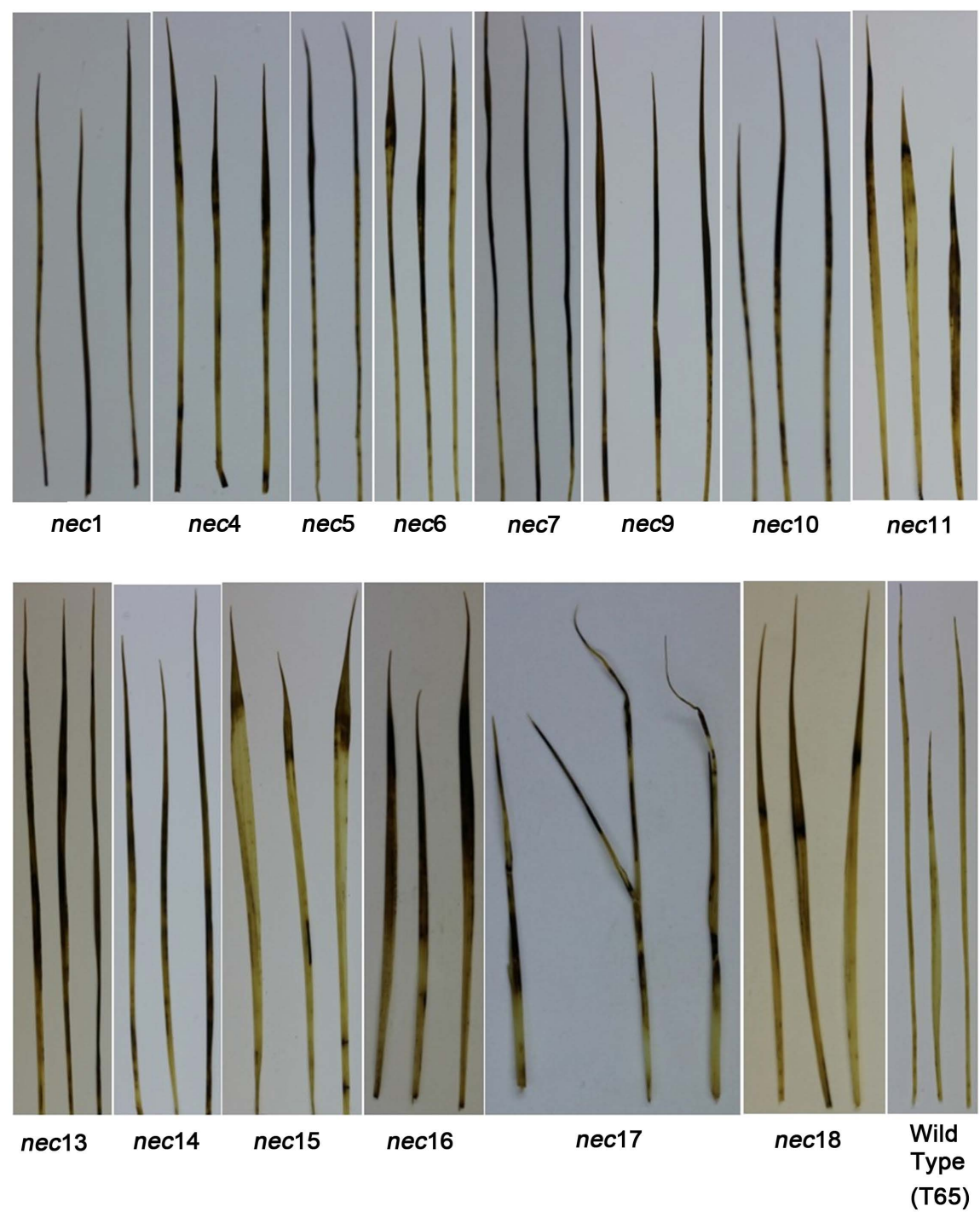

Figure S2. Characterization of mutants for necrotic lethality in rice by DAB staining. 